\title{
Do State Business Climate Indicators Explain Relative Economic Growth at State Borders?
}

Georgeanne M. Artz, Kevin Duncan, Arthur Hall, Peter Orazem

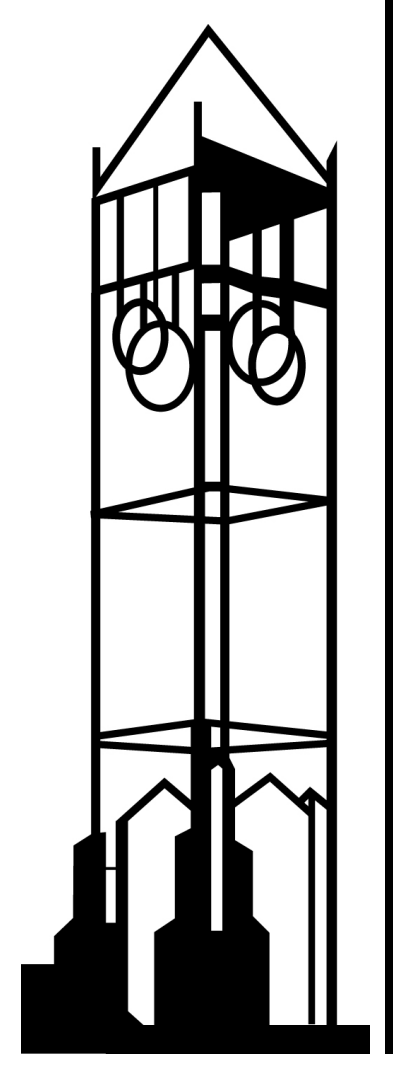

Working Paper No. 14031

October 2014

IOWA STATE UNIVERSITY

Department of Economics

Ames, lowa, 50011-1070 
Do State Business Climate Indicators Explain Relative Economic Growth at State Borders?

Georgeanne Artz ${ }^{\mathrm{a}}$, Kevin Duncan ${ }^{\mathrm{a}}$, Arthur Hall ${ }^{\mathrm{b}}$ and Peter F. Orazem ${ }^{\mathrm{a}}$

October, 2014

\begin{abstract}
This study submits eleven business climate indexes to tests of their ability to predict relative economic performance on either side of state borders. Our results show that most business climate indexes have no ability to predict relative economic growth regardless of how growth is measured. Some are negatively correlated with relative growth. Many are better at reporting past growth than at predicting the future. In the end, the most predictive business climate index is the Grant Thornton Index which was discontinued in 1989.
\end{abstract}

JEL Codes: O4, R1

${ }^{a}$ Iowa State University

${ }^{\mathrm{b}}$ University of Kansas

We thank Matthew Orazem and Liesl Eathington for research assistance. We gratefully acknowledge partial funding for this research from the Koch Foundation. 
Do State Business Climate Indicators Explain Relative Economic Growth at State Borders?

Numerous organizations produce rankings of states and localities on relative business climate. States and localities tout the indexes on which they rank highly in their efforts to attract new or expanding businesses. Politicians use them to demonstrate the success of their policies or to denigrate the policies of incumbents. Indexes are widely disseminated in print and electronic media, often treated as accurate measures of actual economic performance. However, few of the indexes are subject to systematic tests of their predictive power.

This study submits eleven business climate indexes to tests of their ability to predict relative economic performance on either side of state borders. An area's comparative advantage is unlikely to differ on either side of a state boundary, so it is reasonable to assume that firms would be equally successful in either state, other things equal. Furthermore, ease of migration of capital and labor from one side of the border to the other should equalize the marginal products of capital and labor so that productivity shocks in one state would be transmitted quickly to the other. However, states can dampen the forces that would tend to equalize growth to the extent that capital or labor flows respond to state policies. For example, states differ dramatically in the types of taxes imposed, marginal tax rates, training programs, government regulations, support for infrastructure, investments in the arts or education, recreational amenities, or any number of policies that have been alleged to affect business climate. If these differences affect incentives to invest or live in one state relative to another, they can disrupt the free flow of labor and capital across the borders and create gaps in economic performance. As aggregators of the presumed positive and negative effects of these policies, business climate indicators should signal which side of the border has the more favorable prospects for growth. 
State borders are the most logical place to test the performance of these business climate indicators because differences in state policies will have the largest effects on competitors in the same area. Firms located in the interior of the state have the benefit of distance to moderate the adverse consequences of more favorable policies afforded their competitors in other states. In addition, almost all states have multiple borders, meaning that the same business climate can be tested against the variety of competing business climates of their neighboring states.

We impose several tests. The first examines the ability of each index to predict relative economic growth at the border over the next five years relative to its ability to explain relative growth over the past five years. This will tell us whether the index is focused on prediction or simply ranking based on past performance. The second examines whether an index has predictive power in any five year period between 1970 and 2010 regardless of when the index was published. If business climate persists, we may find that predictive power persists as well. Finally, we allow the various business climate indexes to compete against one another in predicting relative economic growth over the 2005-2010 period regardless of when the index was published. Various measures of growth were employed, including changes in aggregate income, per capita income, labor productivity, employment, wages, and population.

Our results show that most business climate indexes have no ability to predict relative economic growth regardless of how growth is measured. Some are negatively correlated with relative growth. Many are better at reporting past growth than at predicting the future. In the end, the most predictive business climate index is the Grant Thornton Index which was discontinued in 1989. 


\section{BACKGROUND ON BUSINESS CLIMATE INDICES}

In 1975, the Fantus Corporation prepared a one-time ranking of state business climates for the Illinois Manufacturers Association. The report was based on Fantus' subjective assessment of 33 different indicators that were believed to affect manufacturing locations. That study was followed in 1979 by the first of a series of annual reports by Grant Thornton that used a weighted aggregation of 18 to 22 factors, with the weights determined by a survey of representatives of various manufacturer's associations. Both studies represented attempts to characterize a state's overall environment for business success, including tax policy, regulatory structure, labor force quality, and quality of life.

Since then, a variety of business climate indexes have been created. State rankings have been published on numerous criteria such as quality of life, cost of living, school quality, tax competitiveness, labor force quality, entrepreneurship, and green jobs. The ranking business has been extended to the metropolitan level. These rankings are reproduced by local newspapers, Chambers of Commerce, and Economic Development Commissions.

The indexes clearly view themselves as in competition with one another. The Corporation for Enterprise Development (CED, 1987, p. 2) stated that, "the Grant Thornton index does not measure the factors important to business success in today's economy. The index and the traditional business climate definition it perpetuates are relics from another time, another economy - an economy based on routine mass production where cheap, low skilled labor is the key to success." In contrast, the CED $(1987$, p. 3$)$ asserted that its index, "provides a more accurate and more comprehensive picture of how state economies are doing in today's economy and, thus, how 'attractive' they really are for business development." Twelve years later, the Progressive Policy Index justified its creation of the State New Economy Index on similar 
grounds. "Unlike some other reports which assess state economic performance or state economic policies, this report focuses more narrowly on a simple question: to what degree does the structure of state economies match the ideal structure of the New Economy?" (Atkinson and Stewart, 2012).

The two early business climate indexes produced by Fantus and Grant Thorton received some attention from academics. ${ }^{1}$ However, since Grant Thornton discontinued its index in 1989, its successors have rarely been subjected to academic scrutiny. Kolko, Neumark and Cuellar Mejia's (2013) study is the first serious published analysis since 1989. Using aggregate state measures of output, employment and wages, they conclude that indexes that focused on simpler tax structures and smaller welfare states tended to perform better in predicting relative state growth. However, business climate indexes had only modest explanatory power in explaining relative state economic growth compared to factors beyond policy influence such as weather, proximity to a major waterway, industrial mix, and population density.

Missing from previous studies of business climate indexes is an effort to control for the endogeneity of government policies concerning growth. As noted by Kolko et al (2013), due to locational, climactic and geological advantages and disadvantages, states will have natural differences in their sectoral comparative advantages and disadvantages. However, governments may alter their tax rates, expenditures and economic development policies to build on these advantages and mitigate disadvantages. Analogously, private investors and financial intermediaries will adjust their strategies in response to perceived local opportunities. Moreover, a state may alter its policies in response to its neighbor's actions. A low marginal income tax rate may have particularly positive impacts when the neighboring state has high marginal rates, but it may have little impact if the neighbor matches the low rate ${ }^{2}$. As a result, cross sectional 
data on government policies and business will reflect their local environments. The same policy may prove effective in one location due to geoclimatic conditions and a neighbor's policies and detrimental in another. A simple cross -sectional analysis that relates state-wide economic growth to state policies without considering these local circumstances may yield unreliable inferences.

For that reason, we conduct our analysis of these business climate indexes where they should have the greatest impact -- on opposite sides of state borders. On either side of the border, naturally occurring comparative advantage should be roughly equivalent. Moreover, policy set at the state level may not reflect the particular local advantages or disadvantages faced on one border versus another. Finally, this strategy will allow us to gauge the success of a state's policies in the context of each of its neighbor's policies. Because most states will have multiple borders, we will be able to test its business climate against multiple alternative states, adding to our ability to identify a particularly good business climate measure.

We list the business climate indexes evaluated in this study in Appendix Table 1. The list includes 11 indexes released between 1975 and 2004. We chose 2004 as our last year so that we have sufficient time to evaluate each index's predictive power for at least five years after release. All of the included indexes were nationally prominent. We only included indexes that provided sufficient detail for us to certify that they were based on objective criteria as opposed to subjective evaluations, and we focused on indexes based on structural measures (e.g. tax policies, factor endowments, or environmental amenities) as opposed to performance measures (e.g. the level or growth of production). We view performance measures as reflective of the outcomes of, rather than the inputs to, the business climate. For example, we exclude the Inc. magazine ranking of state economies published annually in its October edition through the 
1980s. ${ }^{3}$ That ranking was heavily based on growth outcomes such as job growth, business starts, and the percent of fast-growing companies, measures that clearly reflect the past rather than predicting future growth.

The indexes are reported in two ways. Some release explicit scores so that one can assess the magnitude of the business climate gap between states. Others just report a ranking. Either reporting method should predict which state has better conditions for growth at the border. The indexes do not consider the same factors. While all consider various aspects of quality of life, quality of labor or capital inputs, and quality of state or local fiscal and regulatory policies, all also include idiosyncratic factors not considered by other indexes and all place their own explicit or implicit weights on these factors. As information technologies have improved, the indexes have become more complex, both in the number and variety of variables considered and in the statistical methods used to aggregate these variables into a single index.

The business climate indexes break down into three types. The earliest and most common indexes deal with a relatively small number of factors focusing on tax, regulatory and fiscal policies that might affect the cost of doing business. Those include Fantus (FT), Grant Thornton (GT), the Small Business Survival Index (SB), the CED policy index (CEDpi), and the Tax Foundation State Business Tax Climate Index (TF). Another set concentrates on economic freedom, including the Fraser Economic Freedom indexes ( FrN, FrS) and the Clemson-Pacific Research Institute Economic Freedom Index (PRI). These also depend on taxes but place greater emphasis on regulatory restrictions on individual decisions. The third are comprehensive measures that generally give positive value to government industrial policies aimed at stimulating business. Those include the New Economy Index (NE), the remaining two CED 
indexes on economic development policies (CEDdp) and economic capacity (CEDc), and the Beacon Hill Metro and State Competitiveness Report (BH).

To the extent that structural elements used in these indexes change only slowly, we would expect that the indexes have stable rankings of states. Indeed, the inter-temporal correlation between repeated editions of the same index demonstrate a great deal of persistence. ${ }^{4}$ Of five indexes that we observe with a four year gap or more, the smallest inter-temporal correlation is 0.71 , consistent with their presumed use of a consistent world view and methodology. However, there is little agreement between indexes about a state's economic climate. Table 1 reports the cross-correlations between indexes. ${ }^{5}$ Almost two-thirds of the correlations are negative! Half of the remaining correlation coefficients are very small. If business climate were a well-defined statistical measure, we would expect unbiased measures of business climate to be positively correlated. Clearly these indexes are measuring different things.

The exceptions to the rule are the Grant Thornton, Fantus and Pacific Research indexes which are quite highly correlated despite almost a quarter century elapsing between the Fantus and Pacific Research indexes. The New Economy, Center for Enterprise Development: Development Policy and perhaps the Beacon Hill indexes form a second group sharing similar assessments. The two Fraser Economic Freedom indexes represent a third cluster that suggests perhaps they should be just one index.

\section{BUSINESS CLIMATE INDEXES AND RELATIVE GROWTH AT THE BORDER}

The ultimate test of a business climate index is its ability to explain relative economic performance across states. However, states can adjust their tax, expenditure and infrastructure policies in reaction to the state's natural comparative advantages in production, making the 
business climate index endogenous to state economic outcomes. This problem is diminished at the border because the comparative advantages of producing at a given location will not differ from one side of the border to the other. Consequently, we would expect similar economic performance on either side of the border unless there is some outside influence limiting economic opportunity. A properly measured business climate should reflect all the possible barriers that could limit economic outcomes. Moreover, businesses in the center of the state will be somewhat insulated from competition from firms in other states, but firms at the border cannot avoid competition ${ }^{6}$. As a result, if relative business climate matters for business success, it should be most apparent at state borders. ${ }^{7}$

A second reason to focus on relative growth at the state borders is that a state's economic policy should matter most in relation to its neighbors rather than to the country as a whole. With the state as the unit of observation in a cross-sectional analysis, the effect of one state's economic policy is measured against the average policies across all other states. However, by comparing state economic performance relative to its immediate neighbor's growth, we focus on relative economic policy for those two states. It is possible that even a poor economic policy will function well if the neighboring state imposes even poorer policies. On the other hand, relatively enlightened state policies may not have the same effect if the neighboring state is even more enlightened.

The use of relative economic performance at the border can also be justified as a variation of regression discontinuity design (Lee and Lemieux, 2010). Land on either side the border is subject to a sudden change in business climate. Property owners cannot move the land to take advantage of the favorable economic climate on the other side of the border. Therefore, examining the economic activity on either side of the border will reflect the impact of location- 
specific business climates on economic decisions using land on either side of the border, land that otherwise would be equally productive.

We begin by identifying all counties in the U.S. that border another state. In total there are 107 borders including all 48 states of the continental United States. Let $g_{i j t}=\left(\frac{Y_{i j t}}{Y_{i j 0}}\right)$ be the ratio of economic outcomes in period $t$ relative to base period 0 for county $i$ in state $j$. Similarly, let $g_{i j^{\prime} t}=\left(\frac{Y_{i j^{\prime} t}}{Y_{i i j^{\prime} 0}}\right)$ be the corresponding ratio for neighboring county $i$ in state $j^{\prime}$. Let the corresponding business climate indexes in the two states be $b_{j}$ and $b_{j^{\prime}}$. The test of the predictive power of the business climate index is based on the regression

$$
\ln \left(\frac{g_{i j t}}{g_{i j^{\prime} t}}\right)=\beta_{0}+\beta_{I} \ln \left(\frac{b_{j}}{b_{j^{\prime}}}\right)+\varepsilon_{i j j^{\prime} t}
$$

where $\varepsilon_{i j j^{\prime} t}$ is a random error. A finding that $\beta_{I}>0$ indicates that the business climate index has power to explain relative growth across states with the magnitude of $\beta_{I}$ being the elasticity of relative growth with respect to the relative business climate. The index's power to explain the variance in relative growth across states will be measured by the $R^{2}$ statistic.

One might suspect that these business climate indexes do little more than report past growth rather than predicting future growth. We can test that by reversing the specification in 1) to be

$$
\ln \left(\frac{g_{i j-t}}{g_{i j^{\prime}-t}}\right)=\beta_{0^{\prime}}+\beta_{I^{\prime}} \ln \left(\frac{b_{j}}{b_{j^{\prime}}}\right)+\varepsilon_{i j j^{\prime}-t}
$$

where the left-hand-side is the relative growth from period $0-t$ to period 0 . If the business climate index were truly forward looking, it should have more positive predictive power in (1) than in (2). If the business climate index is backward looking, it will do better at explaining the past than the future. 
A complication is that the borders for county $i$ in state $j$ will rarely coincide exactly with the borders of county $i$ in state $j$ '. More typically portions of county $i$ in state $j$ will border two or three counties in state $j$ '. Furthermore, borders will differ in the number of counties, leading to overweighting of long borders or borders with small counties. To prevent problems of double counting counties with multiple neighbors and of overweighting of borders with more counties, we used the strategy illustrated in Figure 1.

Let the total length of the border between the two states be $L_{j j}$. The total border length can be divided into unique, non-overlapping border segments. For example, if county $i$ in state $j$ borders counties 1,2 , and 3 in state $j$, there will be three corresponding non-overlapping border segments with respective lengths of $\ell_{i 11 j^{\prime}}, \ell_{i 12 j^{\prime}}$, and $\ell_{i 13 j^{\prime}}$. These three lengths sum to $\ell_{i \mathrm{j}}$, the total border length of county $i$ in state $j$. Each of the three segments enters regression (1): $\ln \left(\frac{g_{i j t}}{g_{1 j^{\prime} t}}\right)$ with weight $\left(\ell_{i 11 j^{\prime}} / L_{j j^{\prime}}\right) ; \ln \left(\frac{g_{i j t}}{g_{2 j^{\prime} t}}\right)$ with weight $\left(\ell_{i 12 j^{\prime}} / L_{j j^{\prime}}\right)$; and $\ln \left(\frac{g_{i j t}}{g_{3 j^{\prime} t}}\right)$ with weight $\left(\ell_{i 13 j^{\prime}} / L_{j j^{\prime}}\right)$. The weights add up to 1 , so each border enters with a cumulative weight of one, whether there is a single county or twenty counties. ${ }^{8}$ In practice, we found that the weighted regressions yielded estimates similar to a regression that used a correction for clustering on the border which also results in each border entering with the same weight in the regression. Because the cluster correction was more straightforward, we opted to report those results.

We use eight different measures of growth, all available from the Bureau of Economic Analysis' Regional Economic Accounts. ${ }^{9}$ The use of multiple growth measures bypasses concerns that different business climate indexes might be focusing on different aspects of economic success. Four measures reflect elements of total output: aggregate income which includes returns to proprietors as well as compensation, aggregate nonfarm income, income per 
capita and population. If the state's business climate enhances prospects for profit or

productivity growth, it should attract more firm entry and expansion. Personal income is the best available measure of aggregate local output, although it will miss profits that go to nonresident investors and it will include income derived from other areas. Personal income can be decomposed into population and income per capita. Nonfarm income removes the receipts from farms. Because about one-third of U.S. farmland is rented with rental income and government transfer payments going to non-proprietors, farm income may cloud our estimate of local output. A concern is that wage and salary income for residents may be derived from businesses that are located across the border. To address this concern, the remaining four growth indicators are more closely related to the local labor market and worker productivity: average wage per job, output per worker, the county wage bill, and total employment. The county wage bill is the sum of all wages and salaries paid to employees plus the cost of employer provision of benefits such as pensions and insurance, plus the cost of the federally mandated social insurance programs. These are reported by place of work rather than by place of residence, and so these data will include workers commuting from a neighboring state. The wage bill is the largest component of gross state product, representing about $60 \%$ of the total state. Consequently, growth in the wage bill is the closest approximation to growth in county output attributable to labor. Wage bill can be decomposed into its two elements, employment and compensation per job. Absent any restrictions on commuting, wages should equalize on either side of a state border with the more productive side having more employees and faster job growth than its less productive neighbors. Therefore, employment should be more responsive than per worker compensation to relative business climate. ${ }^{10}$ We also have the option of deriving a measure of output per worker by combining wage and salary earnings with proprietor's income and then dividing by employment 
plus proprietors. As with wages, mobile labor should equalize labor productivity growth across the state border and so we would not anticipate that the business climate indexes would be able to predict relative productivity growth.

\section{PREDICTIVE PERFORMANCE OF RELATIVE BUSINESS CLIMATE INDEXES}

We summarize the results of our estimation of equations 1) and 2) in Table 2. Our dependent variables are the eight growth measures applied to the five years preceding the release date of each index and the five years following the release date. These results are reported in the columns labeled "Backcast" and "Forecast" respectively. The five year elapsed time should be sufficient to allow private investment to respond to favorable government policies and to insure that our results are not overly clouded by temporary business cycles. ${ }^{11}$ In addition, because the same national business cycle would be occurring on both sides of the state border, results should not be altered because of shocks to the national economy.

For indexes with multiple editions, we report the average across all releases. For example, with 7 Grant Thornton editions released between 1980 and 1986, we report how many times out of the 7 the coefficient on relative business climate was positive $\left(\beta_{I}>0\right)$, how many times it was significantly positive $\left(\beta_{I} \gg 0\right)$, how many times it returned a significant negative coefficient $\left(\beta_{I} \ll 0\right)$, and the average of the coefficient which we define as the business climate index elasticity $\overline{\epsilon_{I}}$. We also report the average $\mathrm{R}^{2}$ from the regressions to indicate how much of the variation in relative economic growth at the border can be explained by relative values of the business climate index. All results correct for clustering at the state border.

Across all the 5-year forecast regressions across 8 different indicators of economic performance, it is apparent that none of the 11 business climate indexes can explain much of the variation in relative growth at state borders. The best business climate index can explain at most 
$3 \%$ of the variation in relative growth over the next five years. Perhaps growth is primarily driven by fundamentals such as factor endowments and locational comparative advantage and not business climate, or perhaps these measures of business climate are just not that good.

That said, some of the indexes seem better than others. The Grant Thornton index generates the expected positive effect of relative business climate on relative growth over the following five years in 49 of 56 possible cases in the Forecast column including 28 significant positive effects against no significant negative effects. Grant Thornton performs particularly well where an index should be able to predict outcomes, namely growth in aggregate income, wage bill, employment, and population, and it performs less well on relative wages and productivity which should grow similarly on either side of the border. Moreover, the index appears to be truly forward looking in that it performs much better in forecasting than in backcasting. Grant Thornton generated only 12 significant positive effects on growth over the past 5 years against the 28 significant coefficients going forward.

The other index that appeared to perform well is the Corporation for Economic Development Capacity Index which generated 17 significant positive effects on relative growth at the borders against 5 significant negative effects. Like the Grant Thornton index, it appears to be genuinely forward looking as it had only 3 significant positive coefficients in its backcasting regressions.

Some indexes seem to have information for a few outcomes but not others. For example, the Tax Foundation index seems to forecast relative population growth on either side of the border. However, it has strangely negative results in projecting per capita income, average wage and productivity, the series that should be equilibrating on either side of the border. That it failed 
to register positively or negatively for most series suggests that its success in forecasting relative population growth may be a fluke.

Even more perversely, some indexes consistently predict in the wrong direction. The Small Business Survival Index produces consistently incorrect forecasts of relative growth in nonfarm income, population, employment and the wage bill. The Corporation for Economic Development-Policy and Fiscal Policy Indexes also explain relatively more of the variation in relative economic growth outcomes than the other indexes, but in the wrong direction. Across the two series, we have 33 significant negative coefficients against only 4 positive effects. However, they are clearly not trying to replicate the past in that all 32 significant coefficients on relative business climate in the backcast columns are negative.

The New Economy Index was the only one that seemed to look backward rather than forward. It generated 3 significantly negative and no significantly positive coefficients in its forecasting equations, but 6 significantly positive coefficients in its backcasting equations. The remaining indexes had almost no predictive power going either forward or backward, suggesting they had no information to offer on why states grow at different rates on either side of their borders.

\section{DO BUSINESS CLIMATE INDEXES EXPLAIN GROWTH IN ANY PERIOD?}

Our indexes that were issued on multiple years are highly correlated over time, suggesting that their evaluations of relative business climate are quite stable. It may be that a business climate index will do better in some other five year period, even if it does not distinguish itself in the first five years after its release. On the other hand, we may find that a business climate index that appears to have some forecasting ability over the next five years will 
have a similar ability to explain relative growth in other five year periods also. We explore these questions in Table 3.

We divided the period between 1975 and 2010 into seven 5 year periods, and then applied equation 1) to each regardless of the publication date of each index. If a state's business climate is determined by relatively stable government policies regarding taxation, spending and regulation, or if it is fixed by local geoclimatic conditions or naturally occurring geographical advantages, we should find that the index performs similarly across the seven 5-year growth periods spanning 35 years. On the other hand, if business climate evolves over time, then the index should perform best in the period immediately after issuance. As before, an index is less impressive if it performs best looking backward than forward.

We perform this analysis using relative growth in nonfarm income, population, wage bill and employment as our measures of economic outcomes. The first of these is reported in Table 3A. As before, the Grant Thornton index distinguishes itself by generating positive predictions in 45 of 49 cases, 32 of these coefficients being statistically significant. This performance is even more impressive because the Grant Thornton indexes continue to be able to predict relative growth at state borders 20 years after release. It explained at least $3 \%$ of the variation in relative growth for each 5-year period between 1975-2005 before losing predictive power in the 20052010 period.

The CED-Capacity Index also showed some ability to forecast although most of its coefficients were not precise. Its editions from the early 1990s were still able to demonstrate marginally significant positive predictive power 20 years later. The Pacific Research Institute, Small Business Survival, and Tax Foundation indexes were also relatively successful across all periods, although those indexes were released after most of the periods had passed. The rest of 
the indexes were generally unsuccessful regardless of the 5-year period chosen. Most have their best performance, and that a meager showing, looking backward rather than forward.

In the last column we report the common out-of-sample forecast period for all 11 indexes. Only the CED-Capacity Index demonstrates any ability to predict relative economic performance at state borders over that 5 -year period, albeit only explaining about $1 \%$ of the variation in relative growth of nonfarm income.

We repeat the exercise with other growth measures in the next three tables. For population growth, Grant Thornton, PRI, Small Business and Tax Foundation continue to outperform the rest and all manage to generate significant explanatory power in the common outof-sample period of 2005-2010. Efforts to predict wage bill growth were less successful for all of the better performers although the Small Business Index maintains its ability to predict into the 2005-10 period. As for employment growth, the Grant Thornton, Small Business and Tax Foundation Indexes had explanatory power in the 2005-2010 period.

The results from Table 3 show that the relatively successful indexes have some persistence in explaining relative growth across states. The effects are relatively small such that a $10 \%$ difference in business climate index would have less than $1 \%$ difference in relative growth. However, these indexes were relatively stable over time and the estimated effects were quite consistent over long stretches of time. That suggests that a poor business climate index as measured by Grant Thornton could lead to progressively poorer relative economic performance of the state over the following decades.

The best performing indexes including the Grant Thornton, PRI, Small Business and Tax Foundation Indexes, all emphasized relative tax policy in measuring business climate. Of the others, only the CED-Capacity Index managed to have predictive power in the right direction 
and that only for nonfarm income growth. The Beacon Hill, New Economy, Fraser and CEDDevelopment and Fiscal Indexes had no ability to predict forward.

\section{COMPOSITE BUSINESS CLIMATE}

Even the best performing indexes in Table 3 could predict at best $3 \%$ of the variation in economic growth in the 2005-2010 period. That leads to another question: How much of the variance in relative economic performance could we expect a business climate index to explain? To address this question, we stacked all the business climate indexes together into a single regression explaining relative growth of counties at the state borders between 2005-2010. Presuming that these 11 indexes exhaust the available expertise of economic development experts regarding relative growth potential, the combined explanatory power of their forecasts should be an upper-bound measure of the best performance possible by any individual index.

The results are reported in Table 4. Across the four growth measures, the combined forecasts can only explain 3.5-6\% of the variation in economic growth. That suggests that even the very best business climate index can only explain a small fraction of the relative economic performance of states. The great majority of economic performance is due to factors other than measurable business climate.

One might be tempted to examine the individual coefficients in Table 4 and claim that the results demonstrate relative value of the individual indexes in explaining relative performance. In fact, the 2004 Small Business Index does maintain its ability to predict relative growth at the borders as it did in Table 3, at least at the $10^{\text {th }}$ percentile significance level. However, by itself, the Small Business Index could explain no more than $3 \%$ of any of the growth measures, and it could not explain any of the variation in nonfarm income growth. In other words, the Small Business Index is the best performer compared to the others, but that is not a very high bar. 


\section{CONCLUSIONS}

The recent paper by Kolko et al (2013) covered some of the same ground as this study but using states as the unit of observation. As they stress, there are issues of endogenous policy responses to relative growth that could complicate interpretation of their results if states base their policies on business climate indexes. However, our results buttress two findings that they report - that tax based indexes perform better and that most of the sources of growth are outside the influence of economic policy.

This study adds the following stylized facts about business climate indexes:

1) The information content in the better business climate indexes is amazingly persistent. Grant Thornton indexes released in the 1980s remained among the best performing indexes in explaining relative growth across state borders 25 years later.

2) The business climate indexes explain an even smaller fraction of the variation in relative state growth than implied by the Kolko et al (2013) state-level analysis. We estimate that even the very best business climate index could explain at most 3.5-6\% of economic growth across state borders, depending on the measure of growth employed.

3) The indexes that purport to measure local economic innovation, infrastructure, labor market skill, or other indicators of the 'new economy' have no explanatory power and, in fact, explain the past more than the future.

A general conclusion that would follow from both the Kolko et al (2013) analysis and ours is that the business climate indexes lack the scientific rigor typically required of social science research. Indexes claim validity based on included inputs rather than testing forecasts against the data. Both studies suggest that there is considerable potential for improved measures if modern econometric forecasting tools are applied to the task. 
${ }^{1}$ See Plaut and Pluta (1983) and Lane et al (1989) for generally favorable studies. An unpublished paper by Courant and Fulton (1985) concluded that the Grant Thornton index had weak predictive power except in recessions.

${ }^{2}$ For example, Rork (2003) shows that taxes on mobile resources respond positively to rates in neighboring states; a 10 percent home states' tax rates decline between 1.6 and 6.4 percent for a 10 percent decrease in neighboring states' tax rates, depending on the tax.

${ }^{3}$ Our indexes overlap extensively with the indexes studies by Kolko et al (2013). Our set includes the Grant Thornton and FANTUS indexes that predate the Kolko et al study and we exclude the Cato Institute Report Card on the Nation's Governors because it emphasized shortterm policy responses rather than structural measures which we viewed as more permanent and likely to affect long-term private investments.

${ }^{4}$ These are reported in Appendix Table 2.

${ }^{5}$ Because the various editions of an index are highly inter-correlated, we pick an index at the midpoint of the series of releases as the representative index. To make the correlations easier to interpret, indexes for which smaller numbers imply better climates were multiplied by -1 .

${ }^{6}$ While not focused on competition among businesses, McKinnish's (2005) finding that welfare participation in border counties is significantly higher compared with interior counties illustrates this idea.

${ }^{7}$ Previous studies using relative growth at the borders to assess policy effects include Fox (1986) who analyzed retail sales taxes, Holmes (1998) who analyzed of right-to-work laws, Holcombe and Lacombe (2004) who analyzed state income taxation, McKinnish (2005; 2007) who examines welfare participation and welfare-induced migration, and Dube et al (2010) who analyze minimum wage laws.. 
${ }^{8} \mathrm{We}$ exclude the corner counties that border on more than one state, so the cumulative weights sum up to less than one for borders with one or more multistate corners.

${ }^{9}$ Data descriptions and county-level data can be downloaded from http://www.bea.gov/bea/regional/data.htm and are reported in the U.S. Department of Commerce, Bureau of Economic Analysis (2013).

${ }^{10}$ We had thought that natural barriers to travel across the border such as a river might moderate the equilibrating forces across state borders, but we found similar effects when we controlled for rivers and bridges.

${ }^{11}$ Between 1975-2005, there were only four recessions, the longest lasting 16 months. 


\section{References}

Atkinson, Robert D. and Luke A. Stewart. 2012. The 2012 State New Economy Index: Benchmarking Economic Transformation in the States. Washington DC: Information Technology and Innovation Foundation.

Bartik, Timothy J. 1989. "Small Business Start-Ups in the United States: Estimates of the Effects of Characteristics of States." Southern Economic Journal 55:1004-1018.

Bartik, Timothy J., Thomas P. Boehm, and Alan M. Schlottmann. "The Perplexing Literature on Growth and Change." The Review of Regional Studies 33: 1-16.

Becsi, Zsolt.1996. “Do State and Local Taxes Affect Relative State Growth?” Economic Review :18-36.

Brown, Stephen P. A. 2003. "State and Local Policy, Factor Markets and Regional Growth." The Review of Regional Studies 33: 40-60.

Center for Enterprise Development. 1986. "Taken for Granted: How Grant Thornton's Business Climate Index Leads States Astray."

Center for Enterprise Development. 1987. "Making the Grade: The Development Report Card for the States."

Courant, Paul N. and George A. Fulton. 1985. "What Do Business Climate Studies Have To Do with Business?" Institute of Public Policy Studies, Discussion Paper No. 243, The University of Michigan.

Dube, Arindrajit, T. William Lester, and Michael Reich. 2010. "Minimum wage effects across state borders: Estimates using contiguous counties." The Review of Economics and Statistics 92(4): 945-964.

Lane, Julia, Dennis Glennon and James McCabe. 1989. "Measures of Local Business Climate: Alternative Approaches.” Regional Science Perspectives 19: 89-106.

Erickson, Rodney A. 1987. "Business Climate Studies: A Critical Evaluation,” Economic Development Quarterly 2:62-71

Fox, William F. (1986) "Tax Structure and the Location of Economic Activity Along State Borders" National Tax Journal 39 (4): 397-401.

Holcombe, Randall G. and Donald J. Lacombe. 2004. "The Effect of State Income Taxation on Per Capita Income Growth.” Public Finance Review 32 (May):292-312. 
Holcombe, Randall G. and Donald J. Lacombe. 2004. "Using Matched Border Counties for Policy Analysis: The Effects of Entitlement Programs on Female-Headed Households and Female Labor Force Participation.” Eastern Economic Journal 30 (3): 411-425.

Holmes, Thomas J. 1998. "The Effect of State Policies on the Location of Manufacturing: Evidence from State Borders.” Journal of Political Economy 106:667-705.

Granger, Clive W. J. and Ramu Ramanathan. 1984 "Improved Methods of Combining Forecast." Journal of Forecasting

Kolko, Jed, David Neumark, and Marisol Cuellar Mejia. 2013. "What do business climate indexes teach us about state policy and economic growth?" Journal of Regional Science 53(2): 220-255.

Lee, David S. and Thomas Lemieux. 2010. "Regression Discontinuity Designs in Economics." Journal of Economic Literature 48(2): 281-355.

McKinnish, Terra. "Importing the Poor Welfare Magnetism and Cross-Border Welfare Migration." Journal of Human Resources 40, no. 1 (2005): 57-76.

McKinnish, Terra. "Welfare-induced migration at state borders: New evidence from microdata." Journal of public Economics 91, no. 3 (2007): 437-450.

Nickerson, Cynthia, Mitchell Morehart, Todd Kuethe, Jayson Beckman, Jennifer Ifft, and Ryan Williams. 2012. Trends in US farmland values and ownership. US Department of Agriculture, Economic Research Service.

Plaut, Thomas R. and Joseph E. Pluta. 1983. "Business Climate, Taxes and Expenditures, and State Industrial Growth in the United States.” Southern Economic Journal 99-119.

Rork, Jonathan C. 2003. “Coveting Thy Neighbors' Taxation,” National Tax Journal, LVI(4): 775-787.

Sachs, Jeffrey D. and Jordan Rappaport. "The United States as a Coastal Nation." Journal of Economic Growth 8 (1): 5-46.

Skoro, Charles L. 1988. "Rankings of State Business Climates," Economic Development Quarterly. 2 (May): 138-153.

United States Department of Commerce, Bureau of Economic Analysis. 2013. "Local Area Personal Income Methodology.” Methodology Papers. Washington D.C.

Walsh, Michael J. and Jonathan D. Jones. 1988. "More Evidence on the "Border Tax" Effect: The Case of West Virginia, 1979-84." National Tax Journal 41(June): 261-265. 
Table 1: Correlations across Business Climate Indexes, Various Years

\begin{tabular}{|c|c|c|c|c|c|c|c|c|c|c|c|c|}
\hline & GT81 & FT75 & $S B O 0$ & BHOI & NE99 & FrNG04 & FrSG04 & PRI99 & CEDdp 89 & $C E D c 92$ & CEDpi92 & TF03 \\
\hline GT81 & 1 & & & & & & & & & & & \\
\hline FT75 & 0.71 & 1 & & & & & & & & & & \\
\hline SBOO & 0.39 & 0.36 & 1 & & & & & & & & & \\
\hline BHOI & -0.12 & -0.35 & -0.05 & 1 & & & & & & & & \\
\hline NE99 & -0.12 & -0.45 & -0.12 & 0.63 & 1 & & & & & & & \\
\hline FrNG04 & -0.36 & -0.12 & -0.45 & -0.20 & -0.24 & 1 & & & & & & \\
\hline FrSG04 & -0.46 & -0.28 & -0.58 & -0.12 & -0.17 & 0.90 & 1 & & & & & \\
\hline PRI99 & 0.69 & 0.71 & 0.47 & -0.05 & -0.34 & -0.35 & -0.42 & 1 & & & & \\
\hline CEDdp89 & -0.60 & -0.58 & -0.51 & 0.19 & 0.35 & 0.41 & 0.46 & -0.67 & 1 & & & \\
\hline CEDc92 & -0.31 & -0.48 & -0.19 & 0.62 & 0.81 & -0.11 & -0.04 & -0.39 & 0.51 & 1 & & \\
\hline CEDpi92 & -0.23 & -0.27 & -0.54 & 0.07 & 0.07 & 0.34 & 0.50 & -0.21 & -0.46 & -0.12 & 1 & \\
\hline TF03 & 0.50 & 0.35 & 0.75 & 0.10 & 0.07 & -0.52 & -0.61 & 0.44 & -0.52 & -0.04 & -0.63 & 1 \\
\hline GT81 & \multicolumn{12}{|c|}{ Grant Thornton 1981 index } \\
\hline FT75 & \multicolumn{12}{|c|}{$(-1)^{*}$ Fantus 1975 index } \\
\hline$S B O 0$ & \multicolumn{12}{|c|}{$(-1) *$ Small Business Survival Index 2000 index } \\
\hline BHO1 & \multicolumn{12}{|c|}{ Beacon Hill 2001 index } \\
\hline NE99 & \multicolumn{12}{|c|}{ New Economy Index 1999 index } \\
\hline FrNG04 & \multicolumn{12}{|c|}{ Fraser Institute/NCPA Economic Freedom Index: All government 2004 index } \\
\hline $\mathrm{FrSGO4}$ & \multicolumn{12}{|c|}{ Fraser Institute/NCPA Economic Freedom Index: State and Local government 2004 index } \\
\hline PRI99 & \multicolumn{12}{|c|}{$(-1) *$ Clemson/Pacific Research Institute 1999 index } \\
\hline CEDdp89 & \multicolumn{12}{|c|}{ (-1) Corporation for Enterprise Development: economic development policy ranking 1989 index } \\
\hline CEDc92 & \multicolumn{12}{|c|}{ (-1) Corporation for Enterprise Development: capacity ranking 1992 index } \\
\hline CEDpi92 & \multicolumn{12}{|c|}{ Corporation for Enterprise Development: fiscal policy index 1992 index } \\
\hline TF03 & \multicolumn{12}{|c|}{ Tax Foundation 2003 index } \\
\hline
\end{tabular}


Table 2A: Performance of Business Climate Indexes in Predicting Relative 5-Year Growth at State Borders

\section{Beacon Hill}

\section{Growth in: $\quad$ B
Aggregate Income}

$\beta_{I}>0$

$\beta_{I} \gg 0$

$\beta_{I} \ll 0$

$\bar{\varepsilon}_{I}$
$\mathrm{R}^{2}$
CED Policy

Backcast Forecast
CED Capacity

Backcast Forecast

$2 / 10 \quad 5 / 10$

$0 / 10 \quad 4 / 10$

$0 / 10 \quad 1 / 10$

$-0.01 \quad 0.00$

$0.007 \quad 0.017$

CED Fiscal Policy

Backcast Forecast

\begin{tabular}{cccccc}
$0 / 5$ & $0 / 5$ & $2 / 10$ & $5 / 10$ & $0 / 9$ & $2 / 9$ \\
$0 / 5$ & $0 / 5$ & $0 / 10$ & $4 / 10$ & $0 / 9$ & $1 / 9$ \\
$3 / 5$ & $3 / 5$ & $0 / 10$ & $1 / 10$ & $4 / 9$ & $1 / 9$ \\
-0.02 & -0.02 & -0.01 & 0.00 & -0.07 & -0.03 \\
0.01 & 0.026 & 0.007 & 0.017 & 0.018 & 0.010 \\
\hline
\end{tabular}

\begin{tabular}{|c|c|c|c|c|c|c|c|c|}
\hline \multicolumn{9}{|c|}{ Nonfarm Income } \\
\hline$\beta_{I}>0$ & $3 / 4$ & $1 / 4$ & $0 / 5$ & $0 / 5$ & $5 / 10$ & $8 / 10$ & $0 / 9$ & $1 / 9$ \\
\hline$\beta_{I} \gg 0$ & $1 / 4$ & $0 / 4$ & $0 / 5$ & $0 / 5$ & $1 / 10$ & $1 / 10$ & $0 / 9$ & $0 / 9$ \\
\hline$\beta_{I} \ll 0$ & $0 / 4$ & $0 / 4$ & $3 / 5$ & $4 / 5$ & $0 / 10$ & $0 / 10$ & $5 / 9$ & $3 / 9$ \\
\hline $\bar{\varepsilon}_{I}$ & 0.03 & 0.00 & -0.01 & -0.01 & 0.00 & 0.00 & -0.05 & -0.02 \\
\hline $\mathrm{R}^{2}$ & 0.012 & 0.001 & 0.014 & 0.022 & 0.003 & 0.005 & 0.024 & 0.008 \\
\hline \multicolumn{9}{|c|}{ Per capita Income } \\
\hline$\beta_{I}>0$ & $3 / 4$ & $2 / 4$ & $1 / 5$ & $0 / 5$ & $2 / 10$ & $6 / 10$ & $0 / 9$ & $6 / 9$ \\
\hline$\beta_{I} \gg 0$ & $1 / 4$ & $1 / 4$ & $0 / 5$ & $0 / 5$ & $1 / 10$ & $3 / 10$ & $0 / 9$ & $1 / 9$ \\
\hline$\beta_{I} \ll 0$ & $0 / 4$ & $0 / 4$ & $3 / 5$ & $3 / 5$ & $2 / 10$ & $2 / 10$ & $2 / 9$ & $1 / 9$ \\
\hline $\bar{\varepsilon}_{I}$ & 0.03 & 0.01 & -0.01 & -0.01 & 0.00 & 0.00 & -0.03 & 0.00 \\
\hline $\mathrm{R}^{2}$ & 0.005 & 0.003 & 0.016 & 0.018 & 0.010 & 0.014 & 0.013 & 0.008 \\
\hline \multicolumn{9}{|l|}{ Population } \\
\hline$\beta_{I}>0$ & $4 / 4$ & $0 / 4$ & $4 / 4$ & $0 / 4$ & $5 / 10$ & $9 / 10$ & $0 / 9$ & $0 / 9$ \\
\hline$\beta_{I} \gg 0$ & $0 / 4$ & $0 / 4$ & $0 / 4$ & $0 / 4$ & $0 / 10$ & $4 / 10$ & $0 / 9$ & $0 / 9$ \\
\hline$\beta_{I} \ll 0$ & $0 / 4$ & $0 / 4$ & $0 / 4$ & $0 / 4$ & $0 / 10$ & $0 / 10$ & $7 / 9$ & $5 / 9$ \\
\hline $\bar{\varepsilon}_{I}$ & 0.01 & -0.01 & 0.01 & -0.01 & 0.00 & 0.00 & -0.03 & -0.03 \\
\hline $\mathrm{R}^{2}$ & 0.002 & 0.002 & 0.006 & 0.019 & 0.002 & 0.001 & 0.017 & 0.012 \\
\hline \multicolumn{9}{|c|}{ Average Wage } \\
\hline$\beta_{I}>0$ & $1 / 4$ & $0 / 4$ & $1 / 5$ & $2 / 5$ & $10 / 10$ & $6 / 10$ & $2 / 9$ & $0 / 9$ \\
\hline$\beta_{I} \gg 0$ & $1 / 4$ & $0 / 4$ & $0 / 5$ & $1 / 5$ & $0 / 10$ & $0 / 10$ & $0 / 9$ & $0 / 9$ \\
\hline$\beta_{I} \ll 0$ & $0 / 4$ & $0 / 4$ & $0 / 5$ & $3 / 5$ & $0 / 10$ & $0 / 10$ & $0 / 9$ & $2 / 9$ \\
\hline $\bar{\varepsilon}_{I}$ & 0.02 & -0.01 & -0.01 & 0.00 & 0.00 & 0.00 & -0.01 & -0.02 \\
\hline $\mathrm{R}^{2}$ & 0.005 & 0.001 & 0.002 & 0.008 & 0.002 & 0.001 & 0.001 & 0.007 \\
\hline \multicolumn{9}{|l|}{ Productivity } \\
\hline$\beta_{I}>0$ & $2 / 4$ & $2 / 4$ & $1 / 5$ & $2 / 5$ & $7 / 10$ & $4 / 10$ & $2 / 9$ & $1 / 9$ \\
\hline$\beta_{I} \gg 0$ & $1 / 4$ & $0 / 4$ & $0 / 5$ & $1 / 5$ & $0 / 10$ & $0 / 10$ & $0 / 9$ & $0 / 9$ \\
\hline$\beta_{I} \ll 0$ & $0 / 4$ & $0 / 4$ & $2 / 5$ & $3 / 5$ & $0 / 10$ & $0 / 10$ & $1 / 9$ & $2 / 9$ \\
\hline $\bar{\varepsilon}_{I}$ & 0.01 & 0.00 & 0.00 & 0.00 & 0.00 & 0.00 & -0.01 & -0.02 \\
\hline $\mathrm{R}^{2}$ & 0.004 & 0.001 & 0.004 & 0.013 & 0.001 & 0.001 & 0.002 & 0.007 \\
\hline \multicolumn{9}{|l|}{ Wage Bill } \\
\hline$\beta_{I}>0$ & $4 / 4$ & $4 / 4$ & $1 / 5$ & $0 / 5$ & $6 / 10$ & $8 / 10$ & $3 / 9$ & $1 / 9$ \\
\hline$\beta_{I} \gg 0$ & $0 / 4$ & $1 / 4$ & $0 / 5$ & $0 / 5$ & $0 / 10$ & $2 / 10$ & $0 / 9$ & $0 / 9$ \\
\hline$\beta_{I} \ll 0$ & $0 / 4$ & $0 / 4$ & $0 / 5$ & $0 / 5$ & $0 / 10$ & $0 / 10$ & $0 / 9$ & $1 / 9$ \\
\hline $\bar{\varepsilon}_{I}$ & 0.03 & 0.05 & -0.01 & -0.01 & 0.00 & 0.01 & -0.01 & -0.03 \\
\hline $\mathrm{R}^{2}$ & 0.001 & 0.004 & 0.001 & 0.003 & $<0.001$ & 0.003 & 0.006 & 0.005 \\
\hline \multicolumn{9}{|c|}{ Employment } \\
\hline$\beta_{I}>0$ & $4 / 4$ & $4 / 4$ & $2 / 5$ & $0 / 5$ & $6 / 10$ & $10 / 10$ & $3 / 9$ & $2 / 9$ \\
\hline$\beta_{I} \gg 0$ & $0 / 4$ & $0 / 4$ & $0 / 5$ & $0 / 5$ & $1 / 10$ & $3 / 10$ & $0 / 9$ & $0 / 9$ \\
\hline$\beta_{I} \ll 0$ & $0 / 4$ & $0 / 4$ & $0 / 5$ & $1 / 5$ & $2 / 10$ & $2 / 10$ & $2 / 9$ & $2 / 9$ \\
\hline $\bar{\varepsilon}_{I}$ & 0.04 & 0.03 & 0.00 & -0.01 & 0.00 & 0.00 & -0.01 & -0.02 \\
\hline $\mathrm{R}^{2}$ & 0.003 & 0.002 & 0.001 & 0.003 & 0.001 & 0.005 & 0.008 & 0.005 \\
\hline
\end{tabular}


Table 2B: Performance of Business Climate Indexes in Predicting Relative 5-Year Growth at State Borders

Fantus

Growth in: Backcast Forecast Backcast Forecast

\section{Aggregate Income}

$\beta_{I}>0$

$\beta_{I} \gg 0$

$\beta_{I} \ll 0$

$\overline{\varepsilon_{I}}$
$\mathrm{R}^{2}$

$\mathrm{R}^{2}$

\section{Nonfarm Income}

$\beta_{I}>0$

$\beta_{I} \gg 0$

$\beta_{I} \ll 0$

$\overline{\varepsilon_{I}}$
$\mathrm{R}^{2}$

$\begin{array}{cc}0 / 1 & 1 / 1 \\ 0 / 1 & 0 / 1 \\ 1 / 1 & 0 / 1 \\ -0.03 & 0.02 \\ 0.019 & 0.005\end{array}$

Grant Thornton

Backcast Forecast
New Economy

Backcast Forecast

\begin{tabular}{|c|c|c|c|c|c|c|c|c|}
\hline $\mathrm{R}^{2}$ & 0.01 & 0.001 & 0.01 & 0.002 & 0.009 & 0.03 & 0.004 & 0.005 \\
\hline \multicolumn{9}{|c|}{ Per capita Income } \\
\hline$\beta_{I}>0$ & $0 / 1$ & $1 / 1$ & $2 / 2$ & $2 / 2$ & $2 / 7$ & $5 / 7$ & $2 / 2$ & $1 / 2$ \\
\hline$\beta_{I} \gg 0$ & $0 / 1$ & $1 / 1$ & $0 / 2$ & $2 / 2$ & $1 / 7$ & $2 / 7$ & $1 / 2$ & $0 / 2$ \\
\hline$\beta_{I} \ll 0$ & $1 / 1$ & $0 / 1$ & $0 / 2$ & $0 / 2$ & $0 / 7$ & $0 / 7$ & $0 / 2$ & $1 / 2$ \\
\hline$\overline{\varepsilon_{I}}$ & -0.02 & 0.02 & 0.02 & 0.07 & 0.00 & 0.03 & 0.03 & -0.02 \\
\hline $\mathrm{R}^{2}$ & 0.029 & 0.013 & 0.003 & 0.025 & 0.004 & 0.008 & 0.013 & 0.005 \\
\hline \multicolumn{9}{|l|}{ Population } \\
\hline$\beta_{I}>0$ & $0 / 1$ & $0 / 1$ & $0 / 2$ & $0 / 2$ & $7 / 7$ & $7 / 7$ & $2 / 2$ & $1 / 2$ \\
\hline$\beta_{I} \gg 0$ & $0 / 1$ & $0 / 1$ & $0 / 2$ & $0 / 2$ & $3 / 7$ & $7 / 7$ & $0 / 2$ & $0 / 2$ \\
\hline$\beta_{I} \ll 0$ & $0 / 1$ & $0 / 1$ & $2 / 2$ & $2 / 2$ & $0 / 7$ & $0 / 7$ & $0 / 2$ & $0 / 2$ \\
\hline$\overline{\varepsilon_{I}}$ & 0.00 & 0.00 & -0.05 & -0.04 & 0.02 & 0.03 & 0.01 & 0.00 \\
\hline $\mathrm{R}^{2}$ & 0.001 & 0.002 & 0.021 & 0.023 & 0.008 & 0.025 & 0.002 & 0.002 \\
\hline \multicolumn{9}{|c|}{ Average Wage } \\
\hline$\beta_{I}>0$ & $0 / 1$ & $0 / 1$ & $2 / 2$ & $2 / 2$ & $2 / 7$ & $7 / 7$ & $2 / 2$ & $1 / 2$ \\
\hline$\beta_{I} \gg 0$ & $0 / 1$ & $0 / 1$ & $0 / 2$ & $1 / 2$ & $0 / 7$ & $3 / 7$ & $0 / 2$ & $0 / 2$ \\
\hline$\beta_{I} \ll 0$ & $0 / 1$ & $0 / 1$ & $0 / 2$ & $0 / 2$ & $1 / 7$ & $0 / 7$ & $0 / 2$ & $0 / 2$ \\
\hline$\overline{\varepsilon_{I}}$ & -0.01 & 0.00 & 0.02 & 0.03 & -0.01 & 0.02 & 0.01 & -0.01 \\
\hline $\mathrm{R}^{2}$ & 0.005 & 0.003 & 0.004 & 0.009 & 0.002 & 0.006 & 0.001 & 0.002 \\
\hline \multicolumn{9}{|c|}{ Productivity } \\
\hline$\beta_{I}>0$ & $0 / 1$ & $0 / 1$ & $2 / 2$ & $2 / 2$ & $1 / 7$ & $4 / 7$ & $1 / 2$ & $0 / 2$ \\
\hline$\beta_{I} \gg 0$ & $0 / 1$ & $0 / 1$ & $0 / 2$ & $2 / 2$ & $0 / 7$ & $2 / 7$ & $0 / 2$ & $0 / 2$ \\
\hline$\beta_{I} \ll 0$ & $0 / 1$ & $0 / 1$ & $0 / 2$ & $0 / 2$ & $1 / 7$ & $0 / 7$ & $0 / 2$ & $0 / 2$ \\
\hline$\overline{\varepsilon_{I}}$ & -0.01 & 0.00 & 0.03 & 0.04 & -0.01 & 0.01 & 0.00 & -0.02 \\
\hline $\mathrm{R}^{2}$ & 0.006 & 0.003 & 0.006 & 0.008 & 0.002 & 0.006 & 0.002 & 0.003 \\
\hline \multicolumn{9}{|l|}{ Wage Bill } \\
\hline$\beta_{I}>0$ & $0 / 1$ & $0 / 1$ & $1 / 2$ & $0 / 2$ & $6 / 7$ & $7 / 7$ & $2 / 2$ & $2 / 2$ \\
\hline$\beta_{I} \gg 0$ & $0 / 1$ & $0 / 1$ & $0 / 2$ & $0 / 2$ & $1 / 7$ & $1 / 7$ & $1 / 2$ & $0 / 2$ \\
\hline$\beta_{I} \ll 0$ & $0 / 1$ & $0 / 1$ & $0 / 2$ & $1 / 2$ & $0 / 7$ & $0 / 7$ & $0 / 2$ & $0 / 2$ \\
\hline$\overline{\varepsilon_{I}}$ & 0.00 & 0.00 & -0.01 & -0.05 & 0.01 & 0.04 & 0.05 & 0.03 \\
\hline $\mathrm{R}^{2}$ & $<0.001$ & $<0.001$ & $<0.001$ & 0.003 & 0.003 & 0.008 & 0.007 & 0.002 \\
\hline \multicolumn{9}{|c|}{ Employment } \\
\hline$\beta_{I}>0$ & $1 / 1$ & $1 / 1$ & $1 / 2$ & $0 / 2$ & $5 / 7$ & $5 / 7$ & $2 / 2$ & $2 / 2$ \\
\hline$\beta_{I} \gg 0$ & $0 / 1$ & $0 / 1$ & $0 / 2$ & $0 / 2$ & $1 / 7$ & $3 / 7$ & $1 / 2$ & $0 / 2$ \\
\hline$\beta_{I} \ll 0$ & $0 / 1$ & $0 / 1$ & $0 / 2$ & $2 / 2$ & $0 / 7$ & $0 / 7$ & $0 / 2$ & $0 / 2$ \\
\hline$\overline{\varepsilon_{I}}$ & 0.00 & 0.01 & 0.00 & -0.04 & 0.00 & 0.02 & 0.05 & 0.02 \\
\hline $\mathrm{R}^{2}$ & $<0.001$ & 0.005 & $<0.001$ & 0.005 & 0.002 & 0.008 & 0.009 & 0.002 \\
\hline
\end{tabular}


Table 2C: Performance of Business Climate Indexes in Predicting Relative 5-Year Growth at State Borders

\section{Pacific Institute}

Growth in: Backcast Forecast Aggregate Income

\begin{tabular}{|c|c|c|c|c|c|c|}
\hline$\beta_{I}>0$ & $1 / 2$ & $0 / 2$ & $4 / 5$ & $2 / 5$ & $0 / 2$ & $0 / 2$ \\
\hline$\beta_{I} \gg 0$ & $0 / 2$ & $0 / 2$ & $0 / 5$ & $1 / 5$ & $0 / 2$ & $0 / 2$ \\
\hline$\beta_{I} \ll 0$ & $0 / 2$ & $0 / 2$ & $0 / 5$ & $0 / 5$ & $0 / 2$ & $0 / 2$ \\
\hline $\bar{\varepsilon}_{I}$ & 0.02 & -0.04 & 0.03 & 0.02 & -0.04 & -0.05 \\
\hline $\mathrm{R}^{2}$ & 0.006 & 0.003 & 0.005 & 0.005 & 0.003 & 0.007 \\
\hline \multicolumn{7}{|c|}{ Nonfarm Income } \\
\hline$\beta_{I}>0$ & $2 / 2$ & $1 / 2$ & $0 / 5$ & $0 / 5$ & $2 / 2$ & $1 / 2$ \\
\hline$\beta_{I} \gg 0$ & $1 / 2$ & $0 / 2$ & $0 / 5$ & $0 / 5$ & $0 / 2$ & $0 / 2$ \\
\hline$\beta_{I} \ll 0$ & $0 / 2$ & $0 / 2$ & $1 / 5$ & $4 / 5$ & $0 / 2$ & $0 / 2$ \\
\hline $\bar{\varepsilon}_{I}$ & 0.06 & 0.00 & -0.02 & -0.05 & 0.04 & 0.00 \\
\hline $\mathrm{R}^{2}$ & 0.012 & 0.003 & 0.005 & 0.027 & 0.011 & 0.004 \\
\hline \multicolumn{7}{|c|}{ Per capita Income } \\
\hline$\beta_{I}>0$ & $0 / 2$ & $0 / 2$ & $5 / 5$ & $4 / 5$ & $0 / 2$ & $0 / 2$ \\
\hline$\beta_{I} \gg 0$ & $0 / 2$ & $0 / 2$ & $1 / 5$ & $2 / 5$ & $0 / 2$ & $0 / 2$ \\
\hline$\beta_{I} \ll 0$ & $0 / 2$ & $1 / 2$ & $0 / 5$ & $0 / 5$ & $0 / 2$ & $2 / 2$ \\
\hline $\bar{\varepsilon}_{I}$ & -0.01 & -0.04 & 0.02 & 0.02 & -0.02 & -0.08 \\
\hline $\mathrm{R}^{2}$ & 0.001 & 0.006 & 0.004 & 0.007 & 0.0025 & 0.032 \\
\hline \multicolumn{7}{|l|}{ Population } \\
\hline$\beta_{I}>0$ & $2 / 2$ & $2 / 2$ & $0 / 5$ & $0 / 5$ & $2 / 2$ & $2 / 2$ \\
\hline$\beta_{I} \gg 0$ & $1 / 2$ & $1 / 2$ & $0 / 5$ & $0 / 5$ & $1 / 2$ & $2 / 2$ \\
\hline$\beta_{I} \ll 0$ & $0 / 2$ & $0 / 2$ & $1 / 5$ & $5 / 5$ & $0 / 2$ & $0 / 2$ \\
\hline $\bar{\varepsilon}_{I}$ & 0.05 & 0.03 & -0.02 & -0.04 & 0.03 & 0.05 \\
\hline $\mathrm{R}^{2}$ & 0.017 & 0.005 & 0.005 & 0 & 0.008 & 0.022 \\
\hline \multicolumn{7}{|c|}{ Average Wage } \\
\hline$\beta_{I}>0$ & $1 / 2$ & $0 / 2$ & $4 / 5$ & $4 / 5$ & $0 / 2$ & $0 / 2$ \\
\hline$\beta_{I} \gg 0$ & $1 / 2$ & $0 / 2$ & $2 / 5$ & $1 / 5$ & $0 / 2$ & $0 / 2$ \\
\hline$\beta_{I} \ll 0$ & $0 / 2$ & $1 / 2$ & $0 / 5$ & $0 / 5$ & $0 / 2$ & $2 / 2$ \\
\hline $\bar{\varepsilon}_{I}$ & 0.03 & -0.04 & 0.02 & 0.01 & -0.02 & -0.05 \\
\hline $\mathrm{R}^{2}$ & 0.012 & 0.009 & 0.008 & 0.003 & 0.005 & 0.019 \\
\hline \multicolumn{7}{|l|}{ Productivity } \\
\hline$\beta_{I}>0$ & $1 / 2$ & $0 / 2$ & $4 / 5$ & $2 / 5$ & $1 / 2$ & $0 / 2$ \\
\hline$\beta_{I} \gg 0$ & $1 / 2$ & $0 / 2$ & $0 / 5$ & $0 / 5$ & $0 / 2$ & $0 / 2$ \\
\hline$\beta_{I} \ll 0$ & $0 / 2$ & $0 / 2$ & $0 / 5$ & $0 / 5$ & $0 / 2$ & $2 / 2$ \\
\hline $\bar{\varepsilon}_{I}$ & 0.00 & -0.02 & 0.01 & 0.00 & -0.01 & -0.05 \\
\hline $\mathrm{R}^{2}$ & 0.002 & 0.004 & 0.005 & 0.001 & 0.001 & 0.013 \\
\hline \multicolumn{7}{|l|}{ Wage Bill } \\
\hline$\beta_{I}>0$ & $1 / 2$ & $0 / 2$ & $2 / 5$ & $0 / 5$ & $1 / 2$ & $2 / 2$ \\
\hline$\beta_{I} \gg 0$ & $0 / 2$ & $0 / 2$ & $0 / 5$ & $0 / 5$ & $0 / 2$ & $1 / 2$ \\
\hline$\beta_{I} \ll 0$ & $0 / 2$ & $0 / 2$ & $0 / 5$ & $3 / 5$ & $0 / 2$ & $0 / 2$ \\
\hline $\bar{\varepsilon}_{I}$ & 0.00 & -0.04 & -0.01 & -0.05 & 0.00 & 0.08 \\
\hline $\mathrm{R}^{2}$ & 0.004 & 0.003 & $<0.001$ & 0.008 & $<0.001$ & 0.01 \\
\hline \multicolumn{7}{|l|}{ Employment } \\
\hline$\beta_{I}>0$ & $0 / 2$ & $1 / 2$ & $1 / 5$ & $0 / 5$ & $1 / 2$ & $2 / 2$ \\
\hline$\beta_{I} \gg 0$ & $0 / 2$ & $0 / 2$ & $0 / 5$ & $0 / 5$ & $1 / 2$ & $2 / 2$ \\
\hline$\beta_{I} \ll 0$ & $1 / 2$ & $1 / 2$ & $0 / 5$ & $3 / 5$ & $0 / 2$ & $0 / 2$ \\
\hline $\bar{\varepsilon}_{I}$ & -0.04 & -0.04 & -0.01 & -0.03 & 0.00 & 0.06 \\
\hline $\mathrm{R}^{2}$ & 0.006 & 0.004 & $<0.001$ & 0.006 & $<0.001$ & 0.01 \\
\hline
\end{tabular}

Small Business

Backcast Forecast
Tax Foundation

Backcast Forecast 
Table 3A: 5-year growth regressions: relative nonfarm income growth on relative business climate indexes, 1975-2010

\begin{tabular}{|c|c|c|c|c|c|c|c|}
\hline \multirow[b]{2}{*}{ Index } & \multirow{2}{*}{$\begin{array}{l}\text { Index } \\
\text { Year }\end{array}$} & \multicolumn{2}{|c|}{$\begin{array}{l}\text { Occurrences in } \\
\text { the } 7 \text { periods }\end{array}$} & \multicolumn{3}{|c|}{$\begin{array}{c}\mathrm{R}^{2} \text {, period and estimated } \beta_{I} \text { for best 5-year } \\
\text { forecast }^{\mathrm{b}}\end{array}$} & \multirow{2}{*}{$\begin{array}{c}2005-2010^{\mathrm{c}} \\
\beta_{I} \\
\end{array}$} \\
\hline & & $\boldsymbol{\beta}_{\boldsymbol{I}}>0$ & $\beta_{I} \gg 0$ & highest $\mathrm{R}^{2}$ & Best Period & largest $\beta_{I}$ & \\
\hline \multirow[t]{4}{*}{ Beacon Hill } & 2001 & $4 / 7$ & $1 / 7$ & 0.023 & $95-00$ & $0.068 * *$ & 0.01 \\
\hline & 2002 & $4 / 7$ & $1 / 7$ & 0.012 & $95-00$ & $0.049 *$ & 0.012 \\
\hline & 2003 & $4 / 7$ & $0 / 7$ & 0.014 & $95-00$ & 0.057 & 0.021 \\
\hline & 2004 & $4 / 7$ & $1 / 7$ & 0.019 & $95-00$ & $0.064 * *$ & 0.015 \\
\hline \multirow[t]{3}{*}{ CED-Development } & 1989 & $1 / 7$ & $0 / 7$ & 0.004 & $05-10$ & 0.006 & 0.006 \\
\hline & 1990 & $1 / 7$ & $0 / 7$ & $<0.001$ & $05-10$ & 0.002 & 0.002 \\
\hline & 1991 & $0 / 7$ & $0 / 7$ & N/A & N/A & N/A & -0.003 \\
\hline \multirow[t]{7}{*}{ CED-Capacity } & 1990 & $4 / 7$ & $0 / 7$ & 0.005 & $05-10$ & $0.006 * *$ & $0.006^{* *}$ \\
\hline & 1991 & $5 / 7$ & $2 / 7$ & 0.008 & $05-10$ & $0.007 * *$ & $0.007^{* * *}$ \\
\hline & 1992 & $4 / 7$ & $2 / 7$ & 0.011 & $05-10$ & $0.008^{* *}$ & $0.008^{* *}$ \\
\hline & 1993 & $4 / 7$ & $2 / 7$ & 0.009 & $05-10$ & $0.007 * *$ & $0.007 * *$ \\
\hline & 1994 & $4 / 7$ & $0 / 7$ & 0.005 & $80-85$ & 0.007 & 0.004 \\
\hline & 1995 & $4 / 7$ & $0 / 7$ & 0.005 & $80-85$ & 0.007 & 0.003 \\
\hline & 1996 & $4 / 7$ & $1 / 7$ & 0.011 & $95-00$ & $0.009 *$ & 0.003 \\
\hline \multirow[t]{7}{*}{ CED-Fiscal } & 1990 & $1 / 7$ & $0 / 7$ & 0.001 & $75-80$ & 0.008 & -0.0001 \\
\hline & 1991 & $1 / 7$ & $0 / 7$ & 0.001 & $75-80$ & 0.012 & -0.0004 \\
\hline & 1992 & $2 / 7$ & $0 / 7$ & 0.005 & $75-80$ & 0.021 & -0.003 \\
\hline & 1993 & $2 / 7$ & $0 / 7$ & $<0.001$ & $95-00$ & 0.004 & 0.006 \\
\hline & 1994 & $1 / 7$ & $0 / 7$ & $<0.001$ & 05-10 & 0.003 & 0.003 \\
\hline & 1995 & $2 / 7$ & $0 / 7$ & $<0.001$ & $75-80$ & 0.003 & 0.006 \\
\hline & 1996 & $2 / 7$ & $0 / 7$ & $<0.001$ & $75-80$ & 0.002 & 0.0005 \\
\hline Fantus & 1975 & $5 / 7$ & $0 / 7$ & 0.007 & $95-00$ & $0.007 *$ & 0.006 \\
\hline \multirow[t]{2}{*}{ Fraser } & 2004 & $1 / 7$ & $0 / 7$ & 0.006 & 05-10 & 0.031 & 0.031 \\
\hline & 2004 & $1 / 7$ & $0 / 7$ & 0.005 & $05-10$ & 0.030 & 0.03 \\
\hline \multirow[t]{7}{*}{ Grant Thornton } & 1980 & $6 / 7$ & $4 / 7$ & 0.039 & $95-00$ & $0.128 * *$ & -0.017 \\
\hline & 1981 & $6 / 7$ & $6 / 7$ & 0.036 & $95-00$ & $0.042 * *$ & -0.013 \\
\hline & 1982 & $6 / 7$ & $6 / 7$ & 0.033 & $95-00$ & $0.055^{* *}$ & -0.011 \\
\hline & 1983 & $7 / 7$ & $5 / 7$ & 0.032 & $90-95$ & $0.049 * *$ & 0.006 \\
\hline & 1984 & $7 / 7$ & $3 / 7$ & 0.035 & $90-95$ & $0.042^{* *}$ & 0.003 \\
\hline & 1985 & $7 / 7$ & $4 / 7$ & 0.035 & $90-95$ & $0.041^{* *}$ & 0.005 \\
\hline & 1986 & $6 / 7$ & $3 / 7$ & 0.03 & $85-90$ & $0.051 * *$ & -0.007 \\
\hline \multirow[t]{2}{*}{ New Economy } & 1999 & $4 / 7$ & $0 / 7$ & 0.005 & $95-00$ & 0.021 & 0.019 \\
\hline & 2002 & $4 / 7$ & $0 / 7$ & 0.007 & $75-80$ & -0.044 & 0.015 \\
\hline \multirow[t]{2}{*}{ PRI } & 1999 & $5 / 7$ & $3 / 7$ & 0.024 & $90-95$ & $0.109 * *$ & -0.04 \\
\hline & 2004 & $5 / 7$ & $4 / 7$ & 0.021 & $90-95$ & $0.070 * *$ & $-0.055^{* *}$ \\
\hline \multirow[t]{5}{*}{ Small Business } & 2000 & $6 / 7$ & $2 / 7$ & 0.066 & $85-90$ & $0.120^{* *}$ & 0.011 \\
\hline & 2001 & $7 / 7$ & $2 / 7$ & 0.067 & $85-90$ & $0.126^{* *}$ & 0.004 \\
\hline & 2002 & $6 / 7$ & $3 / 7$ & 0.072 & $85-90$ & $0.107 * *$ & 0.003 \\
\hline & 2003 & $7 / 7$ & $3 / 7$ & 0.07 & $85-90$ & $0.109^{* *}$ & 0.004 \\
\hline & 2004 & $5 / 7$ & $3 / 7$ & 0.072 & $85-90$ & $0.124 * *$ & -0.001 \\
\hline \multirow[t]{2}{*}{ Tax Foundation } & 2003 & $6 / 7$ & $2 / 7$ & 0.057 & $85-90$ & $0.135^{* *}$ & -0.036 \\
\hline & 2004 & $6 / 7$ & $3 / 7$ & 0.049 & $85-90$ & $0.129 * *$ & -0.034 \\
\hline
\end{tabular}

${ }^{a}$ Number of positive and significant positive coefficients in the 75 -year periods, 1975 -2010. ${ }^{b}$ Statistics for the best performing regression which has $\beta_{I}>0 . \quad{ }^{\mathrm{c}}$ Estimate for the out of sample period 2005-2010. Standard errors corrected for clustering by border. * significance at the 10 th percentile; ** significance at the 5 th percentile. 
Table 3B: 5-year growth regressions: relative populations growth on relative business climate indexes, 1975-2010

\begin{tabular}{|c|c|c|c|c|c|c|c|}
\hline \multirow[b]{2}{*}{ Index } & \multirow{2}{*}{$\begin{array}{l}\text { Index } \\
\text { Year }\end{array}$} & \multicolumn{2}{|c|}{$\begin{array}{l}\text { Occurrences in } \\
\text { the } 7 \text { periods }\end{array}$} & \multicolumn{3}{|c|}{$\mathrm{R}^{2}$, period and estimated $\beta_{I}$ for best 5-year } & \multirow{2}{*}{$\begin{array}{c}2005-2010 \\
\beta_{I}\end{array}$} \\
\hline & & $\boldsymbol{\beta}_{I}>0$ & $\boldsymbol{\beta}_{\boldsymbol{I}}>0$ & highest $\mathrm{R}^{2}$ & Best Period & largest $\beta_{I}$ & \\
\hline \multirow[t]{4}{*}{ Beacon Hill } & 2001 & $4 / 7$ & $0 / 7$ & 0.001 & $95-00$ & 0.009 & 0.002 \\
\hline & 2002 & $2 / 7$ & $0 / 7$ & 0.001 & $90-95$ & 0.008 & -0.001 \\
\hline & 2003 & $3 / 7$ & $0 / 7$ & 0.001 & $95-00$ & 0.009 & 0.005 \\
\hline & 2004 & $2 / 7$ & $0 / 7$ & $<0.001$ & $90-95$ & 0.0001 & -0.017 \\
\hline \multirow[t]{3}{*}{ CED-Development } & 1989 & $1 / 7$ & $1 / 7$ & 0.023 & $75-80$ & 0.013 & $-0.005^{* *}$ \\
\hline & 1990 & $1 / 7$ & $1 / 7$ & 0.015 & $75-80$ & 0.01 & $-0.005^{*}$ \\
\hline & 1991 & $1 / 7$ & $1 / 7$ & 0.007 & $75-80$ & 0.007 & $-0.004 *$ \\
\hline \multirow[t]{7}{*}{ CED-Capacity } & 1990 & $1 / 7$ & $1 / 7$ & 0.012 & $75-80$ & 0.01 & -0.0002 \\
\hline & 1991 & $4 / 7$ & $0 / 7$ & 0.001 & $75-80$ & 0.002 & -0.001 \\
\hline & 1992 & $4 / 7$ & $0 / 7$ & 0.001 & $75-80$ & 0.002 & -0.001 \\
\hline & 1993 & $4 / 7$ & $0 / 7$ & 0.002 & $75-80$ & 0.003 & -0.002 \\
\hline & 1994 & $5 / 7$ & $0 / 7$ & 0.002 & $75-80$ & 0.004 & $-0.004 *$ \\
\hline & 1995 & $3 / 7$ & $1 / 7$ & 0.005 & $75-80$ & 0.005 & -0.001 \\
\hline & 1996 & $3 / 7$ & $0 / 7$ & 0.003 & $75-80$ & 0.004 & -0.002 \\
\hline \multirow[t]{7}{*}{ CED-Fiscal } & 1990 & $0 / 7$ & $0 / 7$ & N/A & N/A & N/A & $-0.014 * *$ \\
\hline & 1991 & $0 / 7$ & $0 / 7$ & N/A & N/A & N/A & -0.012 \\
\hline & 1992 & $0 / 7$ & $0 / 7$ & N/A & N/A & N/A & -0.007 \\
\hline & 1993 & $0 / 7$ & $0 / 7$ & N/A & N/A & N/A & $-0.020 * *$ \\
\hline & 1994 & $0 / 7$ & $0 / 7$ & N/A & N/A & N/A & $-0.020 * *$ \\
\hline & 1995 & $0 / 7$ & $0 / 7$ & N/A & N/A & N/A & $-0.019 * *$ \\
\hline & 1996 & $0 / 7$ & $0 / 7$ & N/A & N/A & N/A & $-0.020 *$ \\
\hline Fantus & 1975 & $5 / 7$ & $1 / 7$ & 0.008 & $85-90$ & $0.007 *$ & 0.003 \\
\hline \multirow[t]{2}{*}{ Fraser } & 2004 & $0 / 7$ & $0 / 7$ & N/A & N/A & N/A & -0.027 \\
\hline & 2004 & $0 / 7$ & $0 / 7$ & N/A & N/A & N/A & -0.033 \\
\hline \multirow[t]{7}{*}{ Grant Thornton } & 1980 & $7 / 7$ & $5 / 7$ & 0.045 & $95-00$ & $0.1 * *$ & 0.021 \\
\hline & 1981 & $7 / 7$ & $7 / 7$ & 0.027 & $85-90$ & $0.032^{* *}$ & $0.009^{*}$ \\
\hline & 1982 & $7 / 7$ & $6 / 7$ & 0.032 & $85-90$ & $0.047^{* * *}$ & $0.016 * *$ \\
\hline & 1983 & $7 / 7$ & $7 / 7$ & 0.031 & $90-95$ & $0.034 * *$ & $0.012^{*}$ \\
\hline & 1984 & $7 / 7$ & $4 / 7$ & 0.045 & $85-90$ & $0.039^{* *}$ & 0.006 \\
\hline & 1985 & $7 / 7$ & $5 / 7$ & 0.032 & $85-90$ & $0.032^{* *}$ & 0.007 \\
\hline & 1986 & $7 / 7$ & $5 / 7$ & 0.033 & $85-90$ & $0.037 * *$ & 0.001 \\
\hline \multirow[t]{2}{*}{ New Economy } & 1999 & $4 / 7$ & $0 / 7$ & 0.001 & $90-95$ & 0.008 & -0.007 \\
\hline & 2002 & $4 / 7$ & $0 / 7$ & 0.001 & $85-90$ & 0.009 & -0.016 \\
\hline \multirow[t]{2}{*}{ PRI } & 1999 & $6 / 7$ & $4 / 7$ & 0.023 & $95-00$ & $0.076 * *$ & $0.036^{* * *}$ \\
\hline & 2004 & $6 / 7$ & $2 / 7$ & 0.016 & $95-00$ & $0.044 * *$ & 0.010 \\
\hline \multirow[t]{5}{*}{ Small Business } & 2000 & $6 / 7$ & $4 / 7$ & 0.051 & $85-90$ & $0.074 * *$ & $0.039 * *$ \\
\hline & 2001 & $6 / 7$ & $4 / 7$ & 0.051 & $85-90$ & $0.077 * *$ & $0.037 * *$ \\
\hline & 2002 & $6 / 7$ & $5 / 7$ & 0.057 & $85-90$ & $0.067 * *$ & $0.032 * *$ \\
\hline & 2003 & $6 / 7$ & $5 / 7$ & 0.058 & $85-90$ & $0.069^{* *}$ & $0.033 * *$ \\
\hline & 2004 & $6 / 7$ & $5 / 7$ & 0.061 & $85-90$ & $0.08 * *$ & $0.038 * *$ \\
\hline \multirow[t]{2}{*}{ Tax Foundation } & 2003 & $7 / 7$ & $6 / 7$ & 0.043 & $85-90$ & $0.082 * *$ & $0.031 * *$ \\
\hline & 2004 & $7 / 7$ & $6 / 7$ & 0.04 & $85-90$ & $0.081 * *$ & $0.032 * *$ \\
\hline
\end{tabular}


Table 3C: 5-year growth regressions: relative wage-bill growth on relative business climate indexes, 1975-2010

\begin{tabular}{|c|c|c|c|c|c|c|c|}
\hline \multirow[t]{2}{*}{ Index } & \multirow{2}{*}{$\begin{array}{l}\text { Index } \\
\text { Year }\end{array}$} & \multicolumn{2}{|c|}{$\begin{array}{c}\text { Occurrences in the } 7 \\
\text { periods }^{\mathrm{a}}\end{array}$} & \multicolumn{3}{|c|}{$\begin{array}{c}\mathrm{R}^{2}, \text { period and estimated } \beta_{I} \text { for best 5- } \\
\text { year forecast }\end{array}$} & \multirow{2}{*}{$\begin{array}{c}2005-2010 \\
\beta_{I} \\
\end{array}$} \\
\hline & & $\boldsymbol{\beta}_{I}>0$ & $\boldsymbol{\beta}_{\boldsymbol{I}}>0$ & highest $\mathrm{R}^{2}$ & Best Period & largest $\beta_{I}$ & \\
\hline \multirow{4}{*}{ Beacon Hill } & 2001 & $5 / 7$ & $1 / 7$ & 0.01 & $80-85$ & $0.110 * *$ & 0.002 \\
\hline & 2002 & $4 / 7$ & $1 / 7$ & 0.008 & $80-85$ & $0.105^{*}$ & -0.025 \\
\hline & 2003 & $5 / 7$ & $0 / 7$ & 0.007 & $80-85$ & 0.104 & 0.050 \\
\hline & 2004 & $5 / 7$ & $1 / 7$ & 0.021 & $80-85$ & $0.170^{* *}$ & -0.011 \\
\hline \multirow[t]{3}{*}{ CED-Development } & 1989 & $3 / 7$ & $0 / 7$ & 0.003 & $00-05$ & 0.010 & -0.003 \\
\hline & 1990 & $1 / 7$ & $0 / 7$ & $<0.001$ & $75-80$ & 0.002 & -0.002 \\
\hline & 1991 & $3 / 7$ & $0 / 7$ & 0.001 & $95-00$ & 0.006 & $-0.012^{*}$ \\
\hline \multirow{7}{*}{ CED-Capacity } & 1990 & $5 / 7$ & $1 / 7$ & 0.007 & $95-00$ & $0.014 *$ & 0.001 \\
\hline & 1991 & $4 / 7$ & $0 / 7$ & 0.004 & $95-00$ & 0.010 & 0.002 \\
\hline & 1992 & $4 / 7$ & $1 / 7$ & 0.005 & $95-00$ & $0.011^{*}$ & -0.002 \\
\hline & 1993 & $4 / 7$ & $0 / 7$ & 0.003 & $95-00$ & 0.009 & -0.002 \\
\hline & 1994 & $4 / 7$ & $1 / 7$ & 0.006 & $95-00$ & $0.012^{* *}$ & -0.007 \\
\hline & 1995 & $4 / 7$ & $1 / 7$ & 0.007 & $95-00$ & $0.012 * *$ & -0.006 \\
\hline & 1996 & $4 / 7$ & $1 / 7$ & 0.005 & $95-00$ & $0.011^{*}$ & -0.005 \\
\hline \multirow[t]{7}{*}{ CED-Fiscal } & 1990 & $3 / 7$ & $0 / 7$ & 0.005 & $85-90$ & 0.042 & $-0.040^{*}$ \\
\hline & 1991 & $3 / 7$ & $0 / 7$ & 0.001 & $85-90$ & 0.022 & -0.032 \\
\hline & 1992 & $3 / 7$ & $0 / 7$ & $<0.001$ & $80-85$ & 0.008 & -0.015 \\
\hline & 1993 & $3 / 7$ & $1 / 7$ & 0.012 & $85-90$ & $0.100 *$ & $-0.100 * *$ \\
\hline & 1994 & $4 / 7$ & $0 / 7$ & 0.009 & $85-90$ & 0.083 & $-0.077 * *$ \\
\hline & 1995 & $3 / 7$ & $0 / 7$ & 0.008 & $85-90$ & 0.077 & $-0.064 * *$ \\
\hline & 1996 & $2 / 7$ & $1 / 7$ & 0.01 & $85-90$ & $0.085^{*}$ & $-0.064 * *$ \\
\hline Fantus & 1975 & $4 / 7$ & $0 / 7$ & 0.001 & $80-85$ & 0.008 & -0.005 \\
\hline \multirow[t]{2}{*}{ Fraser } & 2004 & $2 / 7$ & $0 / 7$ & 0.006 & $85-90$ & 0.086 & -0.044 \\
\hline & 2004 & $4 / 7$ & $0 / 7$ & 0.001 & $85-90$ & 0.034 & -0.033 \\
\hline \multirow[t]{7}{*}{ Grant Thornton } & 1980 & $4 / 7$ & $0 / 7$ & 0.008 & $85-90$ & 0.145 & 0.040 \\
\hline & 1981 & $4 / 7$ & $0 / 7$ & 0.006 & $05-10$ & 0.029 & 0.029 \\
\hline & 1982 & $5 / 7$ & $1 / 7$ & 0.006 & $80-85$ & $0.061 *$ & 0.030 \\
\hline & 1983 & $6 / 7$ & $0 / 7$ & 0.006 & $05-10$ & 0.034 & 0.033 \\
\hline & 1984 & $4 / 7$ & $0 / 7$ & 0.012 & $85-90$ & $0.058 *$ & 0.018 \\
\hline & 1985 & $6 / 7$ & $1 / 7$ & 0.015 & $85-90$ & 0.063 & 0.022 \\
\hline & 1986 & $5 / 7$ & $1 / 7$ & 0.028 & $85-90$ & $0.097 * *$ & 0.008 \\
\hline \multirow[t]{2}{*}{ New Economy } & 1999 & $5 / 7$ & $0 / 7$ & 0.004 & $00-05$ & 0.039 & 0.013 \\
\hline & 2002 & $5 / 7$ & $2 / 7$ & 0.008 & $95-00$ & $0.068 * *$ & -0.002 \\
\hline \multirow[t]{2}{*}{ PRI } & 1999 & $5 / 7$ & $0 / 7$ & 0.003 & $90-95$ & 0.065 & 0.046 \\
\hline & 2004 & $5 / 7$ & $0 / 7$ & 0.003 & $75-80$ & 0.063 & 0.014 \\
\hline \multirow[t]{5}{*}{ Small Business } & 2000 & $5 / 7$ & $1 / 7$ & 0.009 & $90-95$ & $0.069^{*}$ & 0.056 \\
\hline & 2001 & $4 / 7$ & $2 / 7$ & 0.011 & $05-10$ & $0.073^{* *}$ & $0.073^{* *}$ \\
\hline & 2002 & $5 / 7$ & $2 / 7$ & 0.015 & $05-10$ & $0.068^{* *}$ & $0.068^{* *}$ \\
\hline & 2003 & $5 / 7$ & $2 / 7$ & 0.018 & $05-10$ & $0.076^{* *}$ & $0.076^{* *}$ \\
\hline & 2004 & $6 / 7$ & $2 / 7$ & 0.013 & $90-95$ & $0.083^{*}$ & $0.074 * *$ \\
\hline \multirow[t]{2}{*}{ Tax Foundation } & 2003 & $5 / 7$ & $0 / 7$ & 0.006 & $05-10$ & 0.063 & 0.063 \\
\hline & 2004 & $5 / 7$ & $0 / 7$ & 0.007 & $05-10$ & 0.068 & 0.068 \\
\hline
\end{tabular}




\begin{tabular}{|c|c|c|c|c|c|c|c|}
\hline \multirow[b]{2}{*}{ Index } & \multirow{2}{*}{$\begin{array}{c}\text { Index } \\
\text { Year }\end{array}$} & \multicolumn{2}{|c|}{$\begin{array}{l}\text { Occurrences in } \\
\text { the } 7 \text { periods }^{\mathrm{a}}\end{array}$} & \multicolumn{3}{|c|}{$\begin{array}{c}\mathrm{R}^{2}, \text { period and estimated } \beta_{I} \text { for best 5-year } \\
\text { forecast }^{\mathrm{b}}\end{array}$} & \multirow{2}{*}{$\begin{array}{c}2005-2010 \\
\beta_{I} \\
\end{array}$} \\
\hline & & $\boldsymbol{\beta}_{\boldsymbol{I}}>0$ & $\boldsymbol{\beta}_{I}>0$ & highest $\mathrm{R}^{2}$ & Best Period & largest $\beta_{I}$ & \\
\hline \multirow[t]{4}{*}{ Beacon Hill } & 2001 & $6 / 7$ & $1 / 7$ & 0.008 & $80-85$ & $0.074 *$ & 0.006 \\
\hline & 2002 & $3 / 7$ & $0 / 7$ & 0.004 & $80-85$ & 0.055 & -0.014 \\
\hline & 2003 & $6 / 7$ & $1 / 7$ & 0.008 & $80-85$ & $0.082^{*}$ & 0.032 \\
\hline & 2004 & $6 / 7$ & $1 / 7$ & 0.026 & $80-85$ & $0.130^{* *}$ & 0.007 \\
\hline \multirow[t]{3}{*}{ CED-Development } & 1989 & $2 / 7$ & $0 / 7$ & 0.006 & $95-00$ & 0.011 & -0.004 \\
\hline & 1990 & $2 / 7$ & $0 / 7$ & 0.001 & $75-80$ & 0.007 & -0.007 \\
\hline & 1991 & $3 / 7$ & $0 / 7$ & 0.006 & $95-00$ & 0.010 & $-0.010 * *$ \\
\hline \multirow[t]{7}{*}{ CED-Capacity } & 1990 & $5 / 7$ & $2 / 7$ & 0.008 & $95-00$ & $0.011^{*}$ & 0.002 \\
\hline & 1991 & $5 / 7$ & $0 / 7$ & 0.007 & $95-00$ & 0.011 & 0.001 \\
\hline & 1992 & $4 / 7$ & $1 / 7$ & 0.009 & $00-05$ & $0.011^{* *}$ & -0.001 \\
\hline & 1993 & $4 / 7$ & $1 / 7$ & 0.006 & $00-05$ & $0.010^{*}$ & -0.001 \\
\hline & 1994 & $4 / 7$ & $2 / 7$ & 0.01 & $95-00$ & $0.012^{* *}$ & -0.002 \\
\hline & 1995 & $4 / 7$ & $2 / 7$ & 0.01 & $95-00$ & $0.011^{* *}$ & -0.002 \\
\hline & 1996 & $4 / 7$ & $2 / 7$ & 0.009 & $00-05$ & $0.012^{* *}$ & -0.002 \\
\hline \multirow[t]{7}{*}{ CED-Fiscal } & 1990 & $4 / 7$ & $0 / 7$ & 0.002 & $85-90$ & 0.019 & $-0.028 * *$ \\
\hline & 1991 & $4 / 7$ & $0 / 7$ & 0.002 & $80-85$ & 0.019 & $-0.023^{*}$ \\
\hline & 1992 & $3 / 7$ & $0 / 7$ & 0.001 & $80-85$ & 0.018 & -0.013 \\
\hline & 1993 & $4 / 7$ & $0 / 7$ & 0.006 & $85-90$ & 0.053 & $-0.059 * *$ \\
\hline & 1994 & $4 / 7$ & $0 / 7$ & 0.004 & $75-80$ & 0.038 & $-0.047 * *$ \\
\hline & 1995 & $4 / 7$ & $0 / 7$ & 0.004 & $75-80$ & 0.039 & $-0.041 * *$ \\
\hline & 1996 & $4 / 7$ & $0 / 7$ & 0.004 & $75-80$ & 0.037 & $-0.045 * *$ \\
\hline Fantus & 1975 & $4 / 7$ & $1 / 7$ & 0.005 & $75-80$ & 0.010 & 0.001 \\
\hline \multirow[t]{2}{*}{ Fraser } & 2004 & $2 / 7$ & $0 / 7$ & 0.007 & $85-90$ & 0.066 & -0.031 \\
\hline & 2004 & $4 / 7$ & $0 / 7$ & 0.005 & $75-80$ & 0.058 & -0.024 \\
\hline \multirow[t]{7}{*}{ Grant Thornton } & 1980 & $5 / 7$ & $0 / 7$ & 0.01 & $85-90$ & 0.118 & 0.048 \\
\hline & 1981 & $3 / 7$ & $1 / 7$ & 0.007 & $05-10$ & $0.022 *$ & 0.021 \\
\hline & 1982 & $4 / 7$ & $0 / 7$ & 0.005 & $05-10$ & 0.026 & 0.026 \\
\hline & 1983 & $6 / 7$ & $1 / 7$ & 0.01 & $05-10$ & $0.031 * *$ & $0.031^{* *}$ \\
\hline & 1984 & $5 / 7$ & $2 / 7$ & 0.02 & $85-90$ & $0.055^{* *}$ & $0.025^{*}$ \\
\hline & 1985 & $6 / 7$ & $3 / 7$ & 0.018 & $85-90$ & $0.0506^{*}$ & $0.028 * *$ \\
\hline & 1986 & $6 / 7$ & $1 / 7$ & 0.028 & $85-90$ & $0.072^{* *}$ & 0.023 \\
\hline \multirow[t]{2}{*}{ New Economy } & 1999 & $5 / 7$ & $0 / 7$ & 0.003 & $00-05$ & 0.0266 & 0.013 \\
\hline & 2002 & $6 / 7$ & $1 / 7$ & 0.012 & $95-00$ & $0.069 * *$ & 0.008 \\
\hline \multirow[t]{2}{*}{ PRI } & 1999 & $4 / 7$ & $1 / 7$ & 0.007 & $75-80$ & 0.0956 & 0.022 \\
\hline & 2004 & $4 / 7$ & $1 / 7$ & 0.014 & $75-80$ & 0.095 & 0.002 \\
\hline \multirow[t]{5}{*}{ Small Business } & 2000 & $5 / 7$ & $1 / 7$ & 0.012 & $90-95$ & $0.063^{* *}$ & 0.031 \\
\hline & 2001 & $6 / 7$ & $2 / 7$ & 0.011 & $90-95$ & $0.062 * *$ & $0.046^{* *}$ \\
\hline & 2002 & $5 / 7$ & $2 / 7$ & 0.011 & $90-95$ & $0.0526^{*}$ & $0.041 * *$ \\
\hline & 2003 & $6 / 7$ & $2 / 7$ & 0.013 & $05-10$ & $0.046^{* *}$ & $0.046^{* *}$ \\
\hline & 2004 & $6 / 7$ & $1 / 7$ & 0.012 & $05-10$ & $0.049 * *$ & 0.049 ** \\
\hline \multirow[t]{2}{*}{ Tax Foundation } & 2003 & $4 / 7$ & $0 / 7$ & 0.007 & $05-10$ & 0.045 & 0.045 \\
\hline & 2004 & $4 / 7$ & $2 / 7$ & 0.007 & $90-95$ & 0.0584* & $0.049 *$ \\
\hline
\end{tabular}


Table 4: Regressions of relative growth from 2005-2010 at state borders on all relative state business climate indexes, using the best performing index year.

\begin{tabular}{|c|c|c|c|c|}
\hline Index and Year & Non-Farm Income & Population & Wage Bill & Employment \\
\hline \multirow[t]{2}{*}{ Beacon Hill 2004} & -0.0003 & -0.002 & -0.018 & 0.008 \\
\hline & $(0.01)$ & $(0.16)$ & $(0.30)$ & $(0.23)$ \\
\hline \multirow[t]{2}{*}{ CED-Capacity 1987} & 0.006 & $0.009 *$ & -0.011 & 0.000040 \\
\hline & $(0.64)$ & $(1.66)$ & $(0.71)$ & $(<0.01)$ \\
\hline \multirow[t]{2}{*}{ CED-development 1987} & $-0.013 *$ & 0.0003 & -0.013 & $-0.018 *$ \\
\hline & $(1.89)$ & $(0.07)$ & $(0.78)$ & $(1.86)$ \\
\hline \multirow{2}{*}{ CED-policy 1995} & -0.002 & 0.023 & $-0.116^{*}$ & -0.036 \\
\hline & $(0.04)$ & (1.19) & $(1.82)$ & $(0.99)$ \\
\hline \multirow[t]{2}{*}{ Fantus 1975} & $0.014 * *$ & -0.0001 & $-0.026^{* *}$ & -0.010 \\
\hline & $(2.54)$ & $(0.05)$ & $(2.95)$ & $(1.56)$ \\
\hline \multirow[t]{2}{*}{ Fraser SG 2004} & 0.023 & -0.028 & $0.162 * *$ & $0.092 * *$ \\
\hline & $(0.50)$ & $(1.22)$ & $(2.47)$ & $(2.20)$ \\
\hline \multirow[t]{2}{*}{ Grant Thornton 1982} & -0.022 & 0.012 & 0.039 & 0.020 \\
\hline & (1.32) & (1.03) & $(1.15)$ & $(1.06)$ \\
\hline \multirow[t]{2}{*}{ New Economy 2002} & 0.059 & $-0.049 * *$ & $0.114^{*}$ & 0.056 \\
\hline & $(1.39)$ & $(2.22)$ & $(1.80)$ & $(1.10)$ \\
\hline \multirow[t]{2}{*}{ PRI 1999} & -0.069 & 0.005 & 0.038 & -0.038 \\
\hline & $(1.40)$ & $(0.17)$ & $(0.39)$ & $(0.68)$ \\
\hline \multirow[t]{2}{*}{ Small Business 2004} & $0.072 * *$ & $0.033^{*}$ & $0.088^{*}$ & $0.066^{*}$ \\
\hline & $(2.30)$ & (1.90) & $(1.67)$ & $(1.65)$ \\
\hline \multirow[t]{2}{*}{ Tax Foundation 2004} & $-0.126^{* *}$ & 0.012 & -0.030 & 0.002 \\
\hline & $(2.55)$ & $(0.47)$ & $(0.35)$ & $(0.03)$ \\
\hline \multirow[t]{2}{*}{ Constant } & $-0.015 * *$ & $-0.007 * *$ & 0.011 & 0.001 \\
\hline & $(2.57)$ & $(2.15)$ & $(0.94)$ & $(0.22)$ \\
\hline $\mathrm{N}$ & 1222 & 1222 & 1222 & 1222 \\
\hline R-sq & 0.059 & 0.047 & 0.045 & 0.035 \\
\hline
\end{tabular}


Figure 1: Example of the creation of county pairs based on border segment lengths

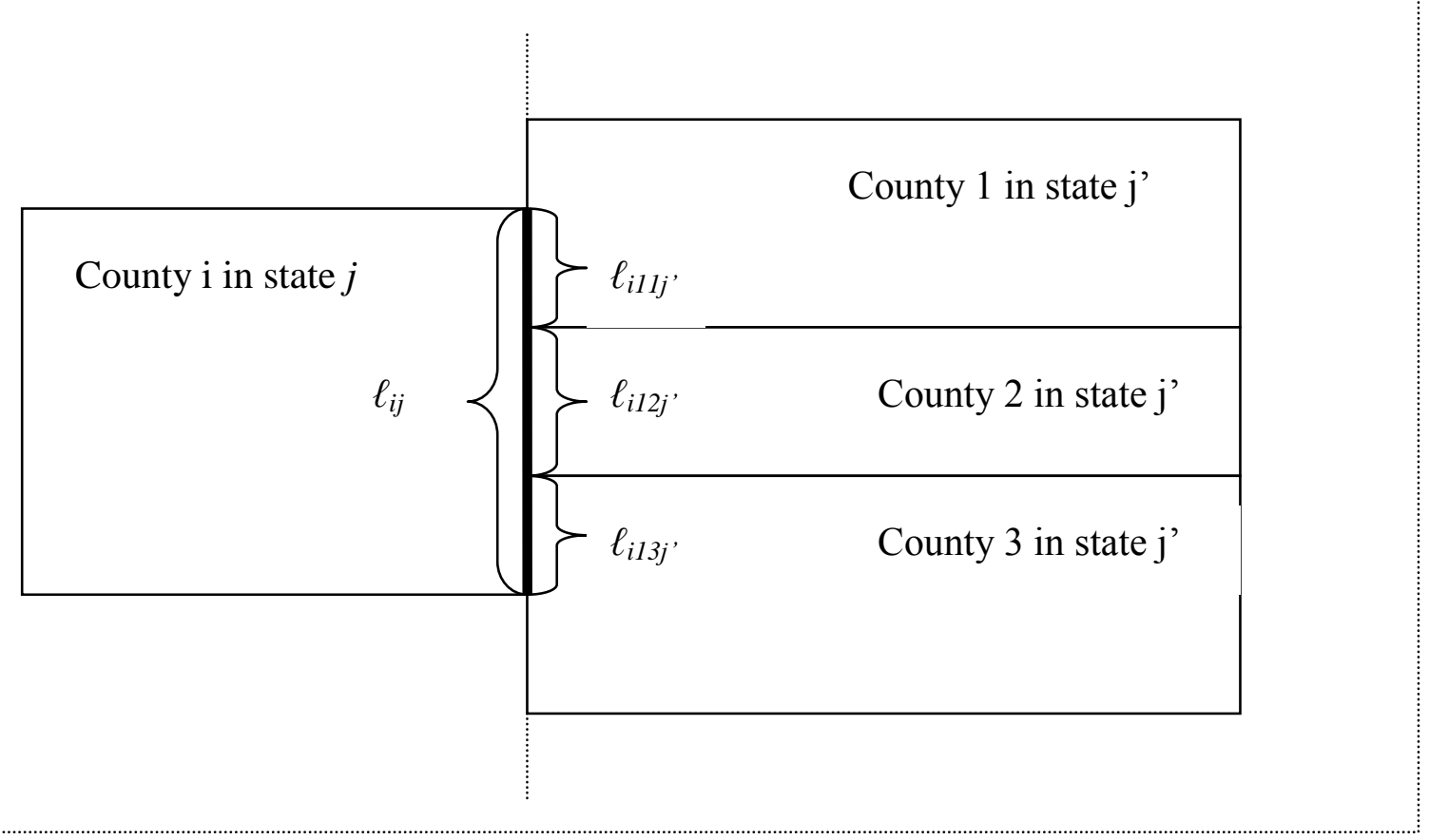


Appendix Table A1: Overview of Business Climate Indexes Used in this Study

\begin{tabular}{|c|c|}
\hline Index & $\begin{array}{rr}\text { Comments } \\
\end{array}$ \\
\hline Fantus Company (1975) & $\begin{array}{l}\text { - Commissioned by the Illinois Manufacturers' Association. } \\
\text { - } 15 \text { measures that primarily related to the cost of doing business. } \\
\text { - Measures appeared to be equally weighted. } \\
\text { - To the authors' knowledge, there are no surviving copies of the original report, only cursory } \\
\text { discussions in secondary sources. }\end{array}$ \\
\hline $\begin{array}{l}\text { Grant Thornton } \\
(1979-1989)\end{array}$ & $\begin{array}{l}\text { - } 1979 \text { study commissioned by the Council of State Manufacturers' Associations (COSMA). } \\
\text { Thereafter, COSMA members participated, but COSMA did not financially sponsor the } \\
\text { annual study. } \\
\text { 18-22 measures primarily associated with the cost of doing business, with a few } \\
\text { demographic and performance measures. } \\
\text { - Measures are weighted based on survey responses regarding measures' importance to } \\
\text { COSMA membership. } \\
\text { - Only the } 48 \text { contiguous states }\end{array}$ \\
\hline $\begin{array}{l}\text { Small Business Survival } \\
\text { Index (2000-2004) }\end{array}$ & $\begin{array}{l}\text { - Product of the Small Business and Entrepreneurship Council (formerly known as the Small } \\
\text { Business Survival Council). http://www.sbsc.org/ } \\
\text { - } 15-21 \text { measures primarily associated with the costs of doing business. Heavily weighted } \\
\text { toward tax policy measures. Small index values indicate a "better" business climate. } \\
\text { - } \quad \text { All measures equally weighted. } \\
\text { - The index dates back to the mid-1990s, but earlier versions were unavailable. }\end{array}$ \\
\hline $\begin{array}{l}\text { Metro Area and State } \\
\text { Competitiveness Report } \\
(2001-2004)\end{array}$ & $\begin{array}{l}\text { - Product of the Beacon Hill Institute at Suffolk University. http://www.beaconhill.org/ } \\
\text { - Approximately } 40 \text { measures categorized into } 5 \text { subindexes: Policy, Security, Infrastructure, } \\
\text { Human Resources, Technology, and Finance. } \\
\text { Each measure is equally weighted within each subindex. Each subindex is equally weighted } \\
\text { in the aggregate index. }\end{array}$ \\
\hline $\begin{array}{l}\text { The State New Economy } \\
\text { Index (1999 \& 2002) }\end{array}$ & $\begin{array}{l}\text { - Product of the Progressive Policy Institute. http://www.neweconomyindex.org/states/2002/ } \\
\text { - } 23 \text { measures categorized into } 5 \text { categories: Knowledge Jobs, Globalization, Economic } \\
\text { Dynamism, Digital Economy, and Innovation Capacity. Measures focus on technology- } \\
\text { related areas. } \\
\text { - Weights applied to each measure to mitigate the influence of closely correlated measures. }\end{array}$ \\
\hline
\end{tabular}




\begin{tabular}{|c|c|}
\hline Index & Comments \\
\hline $\begin{array}{l}\text { Economic Freedom Index } \\
2004 \\
\text { Symbol: FrN (All gov't) } \\
\text { Symbol: FrS (S\&L gov't) }\end{array}$ & $\begin{array}{l}\text { - Product of the Fraser Institute and the National Center for Policy Analysis. } \\
\text { http://www.fraserinstitute.ca/ http://www.ncpa.org/ } \\
\text { - The methodology was applied to both U.S. and Canadian data at both the national and } \\
\text { subnational levels of government. The index is reported at both levels of aggregation. } \\
\text { - } 10 \text { measures related to the size of government and the regulation of markets in three categories: } \\
\text { Size of Government, Takings and Discriminatory Taxation, and Labor Market Freedom. } \\
\text { - Each measure is equally weighted within each subindex. Each subindex is equally weighted in } \\
\text { the aggregate index. }\end{array}$ \\
\hline $\begin{array}{l}\text { The U.S. Economic } \\
\text { Freedom Index (2004) } \\
\text { Economic Freedom in } \\
\text { America's } 50 \text { States (1999) }\end{array}$ & $\begin{array}{l}\text { - The } 2004 \text { index is a product of the Pacific Research Institute (in association with Forbes } \\
\text { Magazine). The } 1999 \text { index is a product of the work of three Clemson University economics } \\
\text { professors. http://www.pacificresearch.org/ http://freedom.clemson.edu/ } \\
\text { - The } 1999 \text { Clemson index (used in the present analysis) is the intellectual forerunner of the } 2004 \\
\text { PRI report. } \\
\text { - Dozens of metrics categorized into five categories: Fiscal Sector, Regulatory Sector, Judicial } \\
\text { Sector, Size of Government, and Welfare Spending. } \\
\text { - Lower index scores means greater economic freedom. } \\
\text { - The } 1999 \text { Index has a two-part weighting procedure. Individual measures within each category } \\
\text { are given decile-based scores, and the decile score of the various measures within each } \\
\text { category are averaged to produce a category score. In 1999, the category scores were } \\
\text { aggregated into a single index using weights from principle components analysis. In } 2004 \text {, the } \\
\text { aggregation used weights from regression coefficients relating the categories to interstate } \\
\text { migration between 1995-2000. }\end{array}$ \\
\hline $\begin{array}{l}\text { Development Report Card } \\
\text { of the States-Policy Index } \\
\text { (1987-1992) } \\
\text { Symbol: CEDdp }\end{array}$ & $\begin{array}{l}\text { - Product of the Corporation for Enterprise Development http://drc.cfed.org/ } \\
\text { - Dozens of measures separated in to eight subindexes. } \\
\text { - Each measure equally weighted in each subindex. Each subindex equally weighted in the } \\
\text { aggregate Policy index. } \\
\text { - Measures focus on the existence of government-based economic development programs. }\end{array}$ \\
\hline
\end{tabular}




\begin{tabular}{|c|c|}
\hline Index & Comments \\
\hline $\begin{array}{l}\text { Development Report Card } \\
\text { of the States-Capacity } \\
\text { Index (1987-2004) } \\
\text { Symbol: CEDc }\end{array}$ & $\begin{array}{l}\text { - Product of the Corporation for Enterprise Development http://drc.cfed.org/ } \\
\text { - 26-30 measures separated into five subindexes: Human Resources, Technology, Finance, } \\
\text { Infrastructure, and Amenities. } \\
\text { - Each measure equally weighted in each subindex. Each subindex equally weighted in } \\
\text { aggregate Capacity index. }\end{array}$ \\
\hline $\begin{array}{l}\text { Development Report Card } \\
\text { of the States-Fiscal Policy } \\
\text { Index (1988-1998) } \\
\text { Symbol: CEDpi }\end{array}$ & $\begin{array}{l}\text { - Product of the Corporation for Enterprise Development http://drc.cfed.org/ } \\
\text { - } 16-18 \text { measures separated into three subindexes: Fiscal Stability and Balance, Tax Fairness, and } \\
\text { Fiscal Equalization. } \\
\text { - Separate reporting of this index began with the } 1988 \text { report (but was part of the } 1987 \text { Policy } \\
\text { Index). } \\
\text { Each measure equally weighted in each subindex. Each subindex equally weighted in } \\
\text { aggregate Capacity index. }\end{array}$ \\
\hline $\begin{array}{l}\text { State Business Tax Climate } \\
\text { Index (2003-2004) }\end{array}$ & $\begin{array}{l}\text { - Product of the Tax Foundation http://www.taxfoundation.org/ } \\
\text { - The } 2003 \text { index was comprised of } 5 \text { major indexes: Corporate Income Tax, Individual Income } \\
\text { Tax, Sales and Gross Receipts Tax, Fiscal Balance, Tax Base Conformity. The major indexes } \\
\text { contain } 18 \text { subindexes and } 32 \text { measures. } \\
\text { - Each major index is weighted equally to form the aggregate index. Each sub-index is weighted } \\
\text { equally within the major indexes. In many instances, a measure equals a sub-index (e.g., tax } \\
\text { rates) } \\
\text { - The } 2004 \text { index replaces adds the Conformity index variables into the other major indexes and } \\
\text { adds an Unemployment Tax index. It also expands the number of sub-indexes and measures, } \\
\text { and alters the weighting scheme to diminish the weights of "yes-or-no" variables. }\end{array}$ \\
\hline
\end{tabular}


Appendix Table A2: Intertemporal correlations for repeated business climate indexes, various years

\begin{tabular}{lccccccccc}
\hline & GT80 & SB00 & NE99 & BH01 & PRI99 & CEDdp87 & CEDc87 & CEDpi88 & TF03 \\
\hline$X(T+1)$ & 0.81 & 0.97 & & 0.97 & & 0.84 & 0.85 & 0.75 & 0.99 \\
$X(T+2)$ & 0.81 & 0.96 & & 0.96 & & 0.84 & 0.83 & 0.74 & \\
$X(T+3)$ & 0.81 & 0.92 & 0.96 & 0.84 & & 0.68 & 0.79 & 0.74 & \\
$X(T+4)$ & 0.76 & & & & & 0.71 & 0.72 & 0.71 & \\
$X(T+5)$ & 0.72 & & & & 0.86 & & 0.73 & 0.61 & \\
$X(T+6)$ & 0.62 & & & & & & 0.73 & 0.61 & \\
$X(T+7)$ & & & & & & & 0.74 & 0.61 & 0.73 \\
$X(T+8)$ & & & & & & & 0.68 & \\
$X(T+9)$ & \\
Correlations represent the earliest available index X at time T with values of the same index taken at time \\
$T+t, t=1,2,9$.
\end{tabular}

